\title{
Adsorption, Separation, and Catalytic Properties of Densified Metal-Organic Frameworks
}

\author{
Manjula I. Nandasiri ${ }^{1}$, Sachin R. Jambovane ${ }^{1}$, B. Peter McGrail ${ }^{2}$, Herbert T. Schaef ${ }^{3}$ \\ and Satish. K. Nune $*^{2}$
}
${ }^{1}$ Environmental Molecular Sciences Laboratory, Pacific Northwest National Laboratory (PNNL), Richland, WA 99354, USA
${ }^{2}$ Energy and Environment Directorate, Pacific Northwest National Laboratory (PNNL), Richland, WA 99354, USA
${ }^{3}$ Physical and Computational Sciences Directorate, Pacific Northwest National Laboratory (PNNL), Richland, WA 99354, USA

*Corresponding author Tel: +001-509 3716632

Email address: satish.nune@pnnl.gov (S. Nune) 


\begin{abstract}
Metal-organic frameworks (MOFs) are one of the widely investigated materials of $21^{\text {st }}$ century due to their unique properties such as structural tailorability, controlled porosity, and crystallinity. These exceptional properties make them promising candidates for various applications including gas adsorption and storage, separation, and catalysis. However, commercial applications of MOFs produced by conventional methods including solvothermal or hydrothermal synthesis are rather limited or restricted because they often produce fine powders. The use of MOF powders for industrial applications often results in pressure drop problems similar to the case with Zeolites and limited robustness against water. To realize these materials for practical applications, densification of MOFs (by increasing pellet density) is routinely employed to form pellets, extrudates or beads to improve the overall density, volumetric adsorption, mechanical and thermal properties. However, the improvements come with some drawbacks such as reduction in overall porosity, surface area, and gravimetric adsorption capacity. Thus, optimizing the properties of densified MOF's by tuning the pellet density is very crucial for realizing these materials for industrial applications. Methods that increase the packing density in MOFs (for example by intentional interpenetration etc.,), which is different from pellet density, is not the scope of this review. In this review, the properties and applications of densified MOFs with different metal clusters and organic linkers are discussed.
\end{abstract}

Abbreviations: MOF, metal organic frameworks; PCP, porous coordination polymers; BASF, Baden Aniline and Soda Factory; DOE, the United States Department of Energy; BDC, 1,4benzene dicarboxlate; VOC, volatile organic compounds; BET, Brunauer-Emmett-Teller; ENG, expanded natural graphite; XRD, X-ray diffraction; $\mathrm{RH}$, relative humidity; $\mathrm{NH}_{3}$, ammonia; $\mathrm{CNCl}$, cyanogen chloride; BSC, broad-spectrum carbon; PVA, polyvinyl alcohol; HPLC, high performance liquid chromatography; IR, infrared; DFT, density functional theory; MIP, mercury intrusion porosimetry; SEM, scanning electron microscopy; BSA, bovine serum albumin; CEC, capillary electrochromatography; nano-LC, nano-liquid chromatography; FTIR, Fourier transform infrared spectroscopy; EDS, energy dispersive spectroscopy; ZIF, Zeolitic imidazolate framework.

Keywords: MOF pellets, Densification, hydrogen storage, volumetric adsorption, thermal conductivity, MOF composites 


\section{Contents}

1

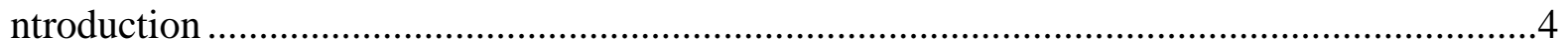

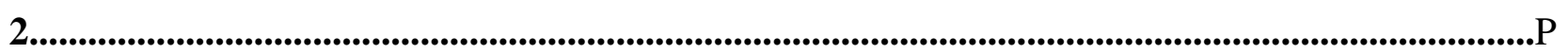

roperties and applications of densified MOFs .................................................................6

2.1 Hydrogen storage properties of densified MOF-5 ..................................................

2.2 Densification of water stable Zr based MOFs .......................................................... 10

2.3 Adsorption and separation properties of densified HKUST-1 ......................................13

2.4 Densification of flexible MOFs (MIL-53) for $\mathrm{CH}_{4} / \mathrm{CO}_{2}$ separation .............................15

2.5 Densified MIL-101(Cr) for adsorption and separation ..............................................16

2.6 Densification of mechanically robust ZIF-8 ......................................................... 19

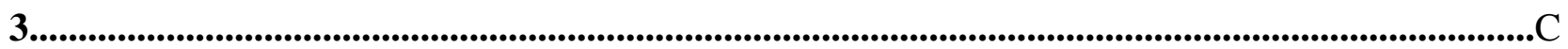

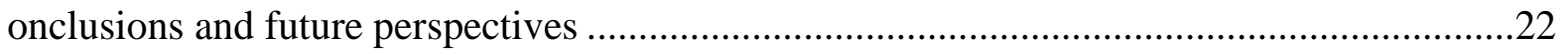

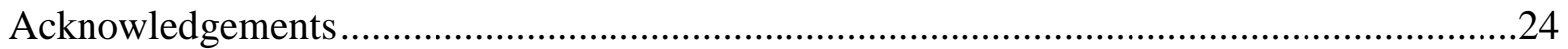

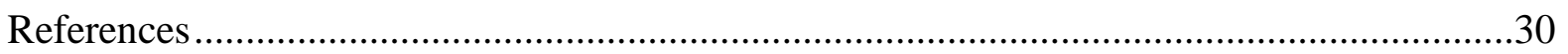




\section{Introduction}

Metal-organic frameworks (MOFs); also known as porous coordination polymers (PCP) are one of the most interesting class of porous materials with extremely high porosity $(50-90 \%$ free volume), very high surface area $\left(1000-8000 \mathrm{~m}^{2} / \mathrm{g}\right)$, and a high degree of crystallinity [1-5]. In MOFs, inorganic building blocks (metal clusters) are connected by organic linkers with strong bonding; relating two separate disciplines in chemistry; organic and inorganic to create a wide range of porous materials with unique properties including chemical and structural tunability [1, 4]. The diverse nature of MOFs due to the variability of metal clusters, judicious choice of structurally tailorable organic linkers, and synthesis methods, structure, size, and functionalities resulted in the ever rising number of MOFs, which were highly published and cited in the last decade $[1,6,7]$. Thus, the various functionalities of MOFs led to a wide range of applications including gas adsorption and storage [8-13], separation [14-16], chemical sensing [17, 18], nanofluids [19, 20] catalysis [21-24], water adsorption [25], toxic gas removal [26], and energy storage [27]. Colloidal nano-sized MOFs exhibit significantly improved adsorption kinetics compared to bulk crystals due to decrease in diffusion path lengths and potential preference of crystal plane interactions [28].

However, using conventional synthesis strategies, MOFs have been often synthesized in powder form with low density, which are technically not suitable for certain industrial applications. Specifically, hydrogen storage; one of the most important applications of MOFs requires high volumetric hydrogen storage density, high thermal conductivity, and better stability in humid and reactive environments, which are lacking in loose powder materials [29, 30]. A similar drawback of low volumetric adsorption capacity was observed when MOF powders were used for carbon dioxide $\left(\mathrm{CO}_{2}\right)$ and methane $\left(\mathrm{CH}_{4}\right)$ storage $[31,32]$. Moreover, MOFs (for eg., MOF-5 etc.,) in powder form do not exhibit high mechanical strength, or good thermal and chemical stability at high temperatures under reactive conditions, which are required for the industrial applications in catalysis and gas separation [33]. The powder materials are also difficult to handle in commercial applications and can cause possible contamination in gas storage tanks [34]. Thus, there is an 
ongoing effort for densification of MOFs to improve the overall performance and overcome those engineering drawbacks and make them suitable for commercial applications. Densification of MOFs can be achieved in the forms of pellets, beads, monoliths, or thin film coatings by mechanical pressing, granulation, extrusion, templating, casting, coating, and thin film processing [35-37]. Recent reviews on these shaping and processing techniques can be found elsewhere [29, 30, 35, 37]. However, the effects of densification on the properties and applications of MOFs have not been reviewed up to date, which will be extensively discussed in this review. Researchers in MOF community have briefly focused to maximize the packing density (by intentional interpenetration) for improved hydrogen storage [38]. Strategies that increase the packing density of MOFs for enhanced gas storage and separation applications are out of the scope of this review.

The most common method in densification of MOFs is making cylindrical pellets with flat ends and desired diameter and thickness by mechanical or hydraulic pressing [30]. The pelletization can be done with or without a binder; but in the former method the adsorption capacity of MOFs may be reduced due to the poor adsorption properties of the added binder. Binders typically improve mechanical strength and thermal conductivity of MOFs [39]. Methods such as chemical activation and hot pressing has been employed to limit the use of binders or in some cases avoid binders completely that resulted in densified MOFs without any loss in adsorption capacities [30]. Therefore, binder-less pellets or monoliths of MOFs are highly recommended as shaped structures in large applications. In extrusion, a MOF-binder composite is pushed through a die with the shape of the structure under the heating and the cooled structure can be cut into desired lengths for suitable applications [30]. The extrusion produces higher volumes of the sample in contrast to mechanical compaction. Templating can also be utilized to obtain MOFs with desired shapes using solid or emulsions templates [30]. Solid templating is the most common method which uses silica monoliths, resorcinol, or zeolite membranes as templates to synthesize MOFs with certain shapes and ordered morphology [30]. The emulsion template techniques utilize a continuous structured phase obtained by sol-gel or polymerization methods and an internal phase emulsion, which is subsequently removed to obtain a porous replica of the emulsion [40]. Spherical beads of MOF with a reasonable micro-porosity have been prepared by emulsiontemplate technique [41]. Thin film coatings of MOFs are also considered as a densified form of MOFs, which have been reviewed by Fischer et al. [37, 42, 43]. Betard and Fischer discussed the 
fundamentals and applications of MOF thin films [42]. Fisher's group has also critically reviewed the status and future applications of thin film coatings of MOFs [37, 43]. Thus, MOF thin films will not be a subject of this review. We will mainly focus on the densified MOFs in the forms of pellets of various materials for specific applications.

\section{Properties and applications of densified MOFs}

The crystal structures and specific applications of various densified MOFs (in the forms of pellets or monoliths) are illustrated in Table 1. MOF-5 has emerged as one of the next generation hydrogen $\left(\mathrm{H}_{2}\right)$ storage materials due to its extremely high gravimetric $\mathrm{H}_{2}$ adsorption capacity [11]. However, low volumetric $\mathrm{H}_{2}$ adsorption capacity, structural decomposition in humid and reactive environments, low density, and poor thermal conductivity of MOF-5 powder materials seriously limit its industrial applications including hydrogen storage [44]. Thus, a collaborative effort has been made by Ford, Baden Aniline and Soda Factory (BASF), and University of Michigan in densifying MOF-5 to improve the adsorption capacities, thermal conductivity, and kinetic stability [45-50]. As a result of their efforts on densification of MOF-5, over $350 \%$ increase in volumetric $\mathrm{H}_{2}$ storage has been achieved for MOF-5 pellets with a density of 0.5 $\mathrm{g} / \mathrm{cm}^{3}$ compared with powder (estimated density of $0.13 \mathrm{~g} / \mathrm{cm}^{3}$ ) [49]. They also recognized several other MOFs such as MOF-177, IRMOF-8, ZIF-8, and $\mathrm{Cu}_{3}(\mathrm{BTC})_{2}$ as promising candidates for $\mathrm{H}_{2}$ storage [51]. The major goal of their effort was to identify the densifying and processing conditions for MOFs to improve their adaptability in commercial $\mathrm{H}_{2}$ storage and enhance the driving range of a hydrogen powered automobile above 300 miles [51]. In addition to MOF-5, densified MOF-177 and MIL-101 (Cr) have shown increased volumetric $\mathrm{H}_{2}$ storage capacities in another effort to achieve the United States Department of Energy's (DOE) targets for hydrogen storage [34, 52-55]. Densified MOFs including $\mathrm{Cu}_{3}(\mathrm{BTC})_{2}, \mathrm{MIL}-101(\mathrm{Cr})$, and $\mathrm{UiO}-66$ have also showed improved volumetric $\mathrm{CO}_{2}$ adsorption capacities compared with powder materials $[32,56,57]$. Densified MIL-53 with flexible organic linkers has mostly utilized for $\mathrm{CO}_{2} / \mathrm{CH}_{4}$ separation, which showed higher $\mathrm{CH}_{4} / \mathrm{CO}_{2}$ separation factors [39, 58-60] compared with MOF powders. To this end, ZIF-8 pellets and monoliths have also been tested for various applications in catalysis, $\mathrm{H}_{2} \mathrm{~S}$ and $\mathrm{N}_{2}$ adsorptions, iodine storage, and separation of hexane isomers and bioalcohols [33, 61-65]. In all the above discussed cases, densified MOFs exhibited improved volumetric adsorption capacities or separation properties. 
Despite the volumetric adsorption capacity enhancement in densified MOFs, in some cases densification resulted in considerable reduction in the surface area and porosity due to the collapsing of some pores during the densification process, especially at high pelletization pressures (eg: $\sim 60 \mathrm{MPa}$ for MOF-5) [49]. Pressurizing above a critical pelletization pressure results in a transformation of crystalline structure to an amorphous phase for all the densified MOFs [33, 49, 66-68]. This critical pelletization pressure exclusively depends on MOF materials and ligands used. MOF-5 maintained its crystalline structure up to a pelletization pressure of 80 $\mathrm{MPa}$ [49]. For $\mathrm{Cu}_{3}(\mathrm{BTC})_{2}, \mathrm{ZIF}-8$, and UiO-66 pellets, the crystalline structure was retained up to a pelletization pressure as high as $200 \mathrm{MPa}[33,67]$. In the units of pellet density, crystallinity was preserved up to a value of $0.5 \mathrm{~g} / \mathrm{cm}^{3}$ for most of the densified MOFs, including MOF-5, MOF-177, and MIL-101. Another drawback of the densification is a substantial decrease in the total gravimetric adsorption capacity due to the decrease in surface area and pore volume. This could be an $\sim 15-20 \%$ reduction compared with powder materials even for the pellets with a modest pellet density of $0.5 \mathrm{~g} / \mathrm{cm}^{3}$. The significant differences in the properties of powdered and densified MOFs are shown in Fig. 1. Densification of MOFs comes with a cost; therefore, a compromise between the volumetric and gravimetric adsorption capacities is needed to obtain the optimal properties for densified MOFs with the increased pellet density. For most of the MOF pellets, the optimized pellet density is closer to $0.5 \mathrm{~g} / \mathrm{cm}^{3}$, which exhibits a greater increase in volumetric adsorption capacity with a minimal decrease in surface area, pore volume, and gravimetric adsorption capacity. In the following sections, we will discuss these optimized properties and applications of various densified MOFs in detail with the evaluation of progress and future challenges in the field.

\subsection{Hydrogen storage properties of densified MOF-5}

Metal organic frameworks with tetrahedral $\left[\mathrm{Zn}_{4} \mathrm{O}\right]^{6+}$ metal clusters and 1,4-benzene dicarboxlate (BDC) organic linkers known as MOF-5 has received significant attention in the MOF research community over the last decade due to its unique properties and applications. For example, MOF-5 has shown high reversible adsorption of hydrogen up to $10 \mathrm{wt}$ \% at low temperatures $(77 \mathrm{~K})$ and moderate pressures of up to 50 bar [44, 69-72], which makes it a leading candidate to achieve the DOE revised target of volumetric and gravimetric hydrogen storage capacity (40 g/L and $5.5 \mathrm{wt} \%$, respectively) for hydrogen storage materials by 2017. Moreover, MOF-5 has been 
used for various applications in catalysis [73, 74], gas separation and purification $[75,76]$, and sensing [77]. Among the important properties of MOF-5, high gravimetric hydrogen storage capacity up to $10 \mathrm{wt} \%$ at $77 \mathrm{~K}$ attracted significant interest in industrial community $[44,78]$. However, conventionally synthesized MOF-5 powders have low density and low thermal conductivity, which are not suitable for industrial applications. MOF-5 has low volumetric hydrogen capacity below the DOE target even though it has extremely high gravimetric hydrogen storage capacity; clearly a drawback of powders [49]. On the other hand, MOF-5 powders are not stable in humid and reactive environments, which can result in decomposition and degradation of its properties [44, 79-81].Thus, densification of MOF-5 powder, largely as pellets has been carried out by a few research groups to overcome these drawbacks [31, 45-50, 82]. These MOF pellets have also been tested for various applications including hydrogen storage [48, 49], methane adsorption [31], and sensing of volatile organic compounds (VOC) [82].

Siegel and co-workers carried out a series of experiments to improve the hydrogen storage capacity and thermal conductivity of MOF-5 through a combination of pelletization and the addition of graphite [45-50]. Even though the pelletization can improve the volumetric $\mathrm{H}_{2}$ uptake and thermal conductivity, it reduces the surface area, pore volume, and gravimetric $\mathrm{H}_{2}$ uptake of MOF-5 [49]. Thus, it is important to find the optimal pellet density with minimal compromise between the volumetric and gravimetric $\mathrm{H}_{2}$ storage capacity. Initially, Purewal et al. prepared pellets with bulk densities of $0.27-1.7 \mathrm{~g} / \mathrm{cm}^{3}$ by compressing the desolvated MOF-5 powder using a manual pellet press inside a high-purity glove box to limit the humid air exposure [49]. The pellet density reached an optimum value of $1.7 \mathrm{~g} / \mathrm{cm}^{3}$ with the varying applied force of 1.3$9.8 \mathrm{kN}$ (kilo Newton). It should be noted that the bulk powder density and single crystal density of MOF-5 are 0.13 and $0.605 \mathrm{~g} / \mathrm{cm}^{3}$, respectively. The densified MOF-5 pellets exhibited improved mechanical strength at higher pellet densities with an average crush density of $71 \mathrm{~N}$ (Newton) at $0.5 \mathrm{~g} / \mathrm{cm}^{3}$ of pellet density. The crystallinity in these pellets was retained to a greater extent even at an applied pressure of $80 \mathrm{MPa}$ in contrast to the amorphous phase of MOF-5 pellets at 3.5 MPa of applied pressure reported by $\mathrm{Hu}$ et al. [66]. The surface area and pore volume of MOFs are believed to decrease for the pellets compared with powder, which is also observed for MOF-5 as shown in Fig. 2(a) [49]. The Brunauer-Emmett-Teller (BET) surface area and pore volume of MOF-5 pellets with a density of $0.5 \mathrm{~g} / \mathrm{cm}^{3}$ were decreased by about $\sim 18 \%$ 
compared with the MOF-5 powder. Although the decrease is anticipated, the decrease was more pronounced at higher pellet densities $\left(57 \%\right.$ at $\left.0.90 \mathrm{~g} / \mathrm{cm}^{3}\right)$. Excess hydrogen adsorption isotherms were collected at $77 \mathrm{~K}$ for MOF-5 powder and pellets and are shown in Fig. 2(b) and (c) [49]. The maximum excess volumetric $\mathrm{H}_{2}$ uptake was enhanced by a factor of $3.5\left(\mathrm{~V}_{\max }=26\right.$ $\mathrm{g} / \mathrm{L}$ ) for the pellet density of $0.5 \mathrm{~g} / \mathrm{cm}^{3}$ with the expense of $15 \%$ decrease in maximum excess gravimetric uptake compared with powder. Furthermore, at high pressure, the total hydrogen storage of MOF-5 pellets with a density of $0.5 \mathrm{~g} / \mathrm{cm}^{3}$ was increased by $40 \%$ at $1160 \mathrm{psi}$ compared with powder. Besides the improved volumetric uptake, the thermal conductivity of MOF-5 pellets also increased with the increasing pellet density, but the maximum thermal conductivity $(0.16 \mathrm{~W} / \mathrm{mK})$ was well below that of single crystal $(0.31 \mathrm{~W} / \mathrm{mK})$ at room temperature [83]. By considering the crush strength, surface area, pore volume, and volumetric and gravimetric $\mathrm{H}_{2}$ uptake of MOF-5 pellets, the optimal performance has been obtained for pellets with an average pellet density of $0.5 \mathrm{~g} / \mathrm{cm}^{3}$ [49].

To this end, Liu et al. made an effort to further improve the thermal conductivity of optimized MOF-5 pellets (density of $0.5 \mathrm{~g} / \mathrm{cm}^{3}$ ) with the addition of expanded natural graphite (ENG) [45]. Interestingly, there was no detrimental effect of ENG addition on the crystalline structure of MOF-5 pellets. Instead, ENG addition reduced the amorphization of MOF-5 pellets at higher pellet densities. ENG additions of 1, 5, and $10 \mathrm{wt}$ \% slightly increased the BET surface area of neat MOF-5 pellets with a density of $0.5 \mathrm{~g} / \mathrm{cm}^{3}$. The pore volume also followed the same trend. 1 wt.\% ENG addition did not significantly improve the thermal conductivity of neat MOF-5 pellets, but 5 and $10 \mathrm{wt} . \%$ ENG additions had a significant impact by enhancing the thermal conductivity by a factor of 3 and 5 compared with neat pellets as shown in Fig. 3 [45]. Addition of $5 \mathrm{wt} . \%$ ENG to MOF-5 pellets reached the thermal conductivity $(0.3 \mathrm{~W} / \mathrm{mK})$ of single crystal MOF-5 [83]. The increase in thermal conductivity by the addition of $10 \mathrm{wt}$.\% ENG to the MOF5 pellets (density of $0.5 \mathrm{~g} / \mathrm{cm}^{3}$ ) comes with a cost of reduction in excess volumetric and gravimetric $\mathrm{H}_{2}$ uptake by 12 and $13 \%$ respectively. [48]. Thus, the best compromise between the enhanced thermal conductivity, improved volumetric $\mathrm{H}_{2}$ storage, and reduced excess gravimetric $\mathrm{H}_{2}$ uptake was obtained for 5-10 wt.\% ENG added MOF-5 composites with a pellet density of $0.5 \mathrm{~g} / \mathrm{cm}^{3}[45,48]$. Xu et al. further studied the permeability and diffusivity of $\mathrm{H}_{2}$ in these pellets with optimal properties [50]. Hydrogen permeability decreases with increasing pellet density and also the $\mathrm{H}_{2}$ diffusivity decreased exponentially with increasing pellet density. However, in 
contrast, addition of ENG enhanced the $\mathrm{H}_{2}$ permeability at $296 \mathrm{~K}$ for MOF-5 pellets with densities lower than $0.4 \mathrm{~g} / \mathrm{cm}^{3}$ [50]. An interesting anisotropic thermal transport behavior of MOF-5/ENG composites was observed by Ming et al. [46]. MOF-5/ ENG (5 wt. \%) composites displayed 2-4 times higher thermal conductivity in the direction perpendicular to the pressing direction than in the pressing direction. The thermal conductivity was further improved by an order of magnitude by fabricating layered composites with alternative layers of MOF-5 and ENG [46].

The kinetic stability of MOFs in different reactive environments is very important for industrial applications and it is a main limiting factor for the commercialization of MOFs. Therefore, Ming et al. evaluated the stability of MOF-5 powder and pellets in humid environments using controlled experiments [47]. MOF-5 powder was pretty stable in modest humid conditions (relative humidity $(\mathrm{RH})<45 \%$ ) for short exposure times ( $<2$ hours). However, the BET surface area and maximum $\mathrm{H}_{2}$ uptake decreased significantly by more than $50 \%$ under higher humid conditions (> 24 hours at $61 \%$ of $\mathrm{RH}$ ) and longer exposures (> 66 hours at $45 \%$ of $\mathrm{RH}$ ). Furthermore, MOF-5 powder completely lost its hydrogen storage ability after exposures to $61 \%$ of $\mathrm{RH}$ for more than 48 hours. The instability of MOF-5 powder under these conditions was attributed to an irreversible structural change, which was also confirmed by powder X-ray diffraction (XRD) with the formation of a new phase [47]. This new phase $\left(\mathrm{ZnBDC} \cdot \mathrm{XH}_{2} \mathrm{O}\right)$ is less favorable to hydrogen storage may be due to the loss of porosity and surface area. Hence, Ming et al. have also investigated the properties of MOF-5 pellets under similar RH conditions. The pellets with a density of $0.36 \mathrm{~g} / \mathrm{cm}^{3}$ showed a better kinetic stability compared with powder even after 24 hours exposure at $45 \%$ of $\mathrm{RH}$. In contrast, a similar decrease in excess $\mathrm{H}_{2}$ uptake was observed for MOF-5 powder after 2 hour exposure at $45 \%$ of RH. The improved resistance of MOF-5 pellets against water at moderate humidity levels was attributed to the reduced water permeation into the pellets. However, a significant decrease in maximum $\mathrm{H}_{2}$ uptake by $\sim 50 \%$ was still observed at higher humidity levels (61\% of RH) and longer exposures (> 24 hours). Furthermore, MOF-5 pellets also completely lost their hydrogen storage ability like powder after exposures to $61 \%$ of RH for 66 hours. Thus, it was concluded that the longer exposures at higher humidity levels are detrimental for the hydrogen storage capacity of MOF-5 even after the densification, which may only slow down the degradation of MOF-5 under humid conditions. Moreover, the influence of ENG addition on the stability of MOF-5 pellets under humid 
conditions was also studied using MOF-5/ENG (5 wt.\%) pellets with the optimum properties. The kinetic stability of ENG added MOF-5 pellets was similar to that of neat MOF-5 pellets. Based on these results, densification of MOFs can be considered as an alternate cost effective approach for improving the stability of MOFs against humid environments.

\subsection{Densification of water stable Zr-based MOFs}

Zr-based MOFs such as UiO-66 have exhibited excellent chemical and thermal stabilities toward the moisture and acids and structural stability under high mechanical pressures [84, 85]. UiO-66 has been synthesized based on the $\mathrm{Zr}_{6} \mathrm{O}_{4}(\mathrm{OH})_{4}$ octahedral groups and BDC linkers. These ultrastable Zr-based MOFs have been heavily investigated for applications in gas adsorption [57, $86,87]$, separation $[67,88,89]$, and catalysis [90,91]. There have been a few studies on pelletization of UiO-66 in order to improve their properties [57, 67, 88, 91]. Peterson et al. studied ammonia $\left(\mathrm{NH}_{3}\right)$ and cyanogen chloride $(\mathrm{CNCl})$ toxic gas removal properties of amino UiO-66 pellets [67]. Amino-UiO-66 pellets were prepared by pressing powder with varying applied pressures from 5000 to 100000 psi. The pelletization did not alter the crystalline properties of UiO-66 up to 25000 psi of applied pressure, but samples showed reduced crystallinity at 100,000 psi. The BET surface area was reduced by about $5 \%$ and $14 \%$ for the samples pressed at 5000 and $10000 \mathrm{psi}$, respectively compared with that of powder $\left(1182 \mathrm{~m}^{2} / \mathrm{g}\right)$ with no significant change in the pore volume $\left(0.5 \mathrm{~cm}^{3} / \mathrm{g}\right)$. However, both the surface area and pore volume was reduced by $26 \%$ and $12 \%$, respectively for the sample pressed at high pressure 25000 psi. Furthermore, the effects of pelletization pressure on $\mathrm{NH}_{3}$ and $\mathrm{CNCl}$ uptake were systematically investigated. $\mathrm{NH}_{3}$ uptake showed a decrease of $33 \%$ at 25000 psi compared with that of UiO-66- $\mathrm{NH}_{2}$ powder $(3.3 \mathrm{~mol} / \mathrm{Kg})$. Moreover, $\mathrm{NH}_{3}$ uptake decreased with the increased pelletization pressure under both dry and humid conditions. A similar trend was observed for the $\mathrm{CNCl}$ uptake with the increased pelletization pressure with $\mathrm{UiO}-66$ powder showing the maximum $\mathrm{CNCl}$ loading of $4.1 \mathrm{~mol} / \mathrm{Kg}$. At $5000 \mathrm{psi}$, no significant decrease in adsorption capacities of UiO-66 for $\mathrm{NH}_{3}$ and $\mathrm{CNCl}$ was observed compared with that of powder, therefore, for breakthrough testing, pellets pressurized at 5000 psi were selected to test and compare with $3 \mathrm{M}$ broad-spectrum carbon (BSC). Breakthrough curves showed a much better $\mathrm{NH}_{3}$ and $\mathrm{CNCl}$ removal in BSC despite the high capacities in amino-UiO-66 pellets. These results suggest that 
amino-UiO-66 lacks the required mass transfer kinetics to use in a filter for the removal of $\mathrm{NH}_{3}$ and $\mathrm{CNCl}$ and needs further improvement in diffusion properties [67].

Kim et al. carried out a scale-up synthesis of UiO-66 in a $100 \mathrm{~L}$ pilot scale batch reactor (UiO66(L)) for industrial applications and its properties were investigated by making pellets using extrusion [57]. In this study, UiO-66(L) pellets were prepared by extrusion using polyvinyl alcohol (PVA) as a binder. The extruded $\mathrm{UiO}(66)$ was cut into uniform size pellets to investigate $\mathrm{CO}_{2}$ adsorption and catalytic properties. The crystalline structure and BET surface area of UiO$66(\mathrm{~L})$ powder were comparable with that of standard UiO-66 $\left(1387 \mathrm{~m}^{2} / \mathrm{g}\right)$. UiO-66(L) powder showed $\mathrm{CO}_{2}$ adsorption capacity of $191 \mathrm{mg} / \mathrm{g}$ at 20 bar and ground/sieved UiO-66(L) pellets exhibited similar $\mathrm{CO}_{2}$ adsorption capacities and $\mathrm{CO}_{2} / \mathrm{N}_{2}$ selectivities [57]. However, the $\mathrm{CO}_{2}$ adsorption capacity decreased slightly with the increased particle size of ground/sieved UiO66(L) pellets as shown in Fig. 4(a) and (b). Both UiO-66(L) powder and pellets were also tested as catalysts for $\mathrm{CO}_{2}$ cycloaddition of styrene oxide, which showed similar conversion rates of 94\% and 92\%, respectively as shown in Fig. 4(c) [57].

The high performance liquid chromatographic (HPLC) separation of UiO-66/Poly(MAA-coEDMA) composite monoliths was studied and compared with that of pure UiO-66 by Fu et al. [88]. UiO-66 incorporated poly(MAA-co-EDMA) monoliths were prepared using a thermal initiated methacrylate polymerization technique. UiO-66 incorporation increased the surface area of poly(MAA-co-EDMA) monoliths from 192.6 to $321.4 \mathrm{~m}^{2} / \mathrm{g}$ [88]. UiO-66 incorporated poly(MAA-co-EDMA) monoliths showed enhanced HPLC separation of small molecules including aromatic hydrocarbons, anilines, acid phenols, and naphthyl substitutes compared with pristine poly(MAA-co-EDMA) monoliths [88]. Pristine poly(MAA-co-EDMA) monoliths showed very weak retention of all small molecules with a poor column efficiency of $2967-8218$ plates per meter. In contrast, UiO-66 incorporated monoliths showed enhanced column efficiency (28,800 plates per meter for 2,6-dimethylphenol) with high resolution and good reproducibility. It was concluded that the enhanced HPLC separation of small molecules by UiO66 incorporated poly(MAA-co-EDMA) monoliths is due to the $\pi$ - $\pi$ interactions, hydrophobic interactions, and interactions between nitrogen atoms in the analytes and the $\mathrm{Zr}$ active sites in $\mathrm{UiO}-66$ [88]. 
UiO-66 pellets have also been tested for the adsorption of isomeric hydrocarbons such as hexane and xylene [92, 93]. Barcia and co-workers first reported the reverse shape selectivity of hexane and xylene isomers by UiO-66 pellets prepared by infrared (IR) press, where the rotational freedom of isomers in small cavities control the adsorption properties [92]. The UiO-66 powder was compacted at applied pressures of 650 and $2000 \mathrm{Kg} / \mathrm{cm}^{2}$ for hexane and xylene adsorptions, respectively. The BET surface area of the UiO-66 pellet pressed at $650 \mathrm{Kg} / \mathrm{cm}^{2}$ was $5 \%$ lower than that of UiO-66 powder $\left(1002 \mathrm{~m}^{2} / \mathrm{g}\right)$. The total adsorption capacity of hexane isomers for UiO-66 pellets was in the range of 7-10 wt.\% and comparable with that of zeolite. The preferential adsorption of di-branched isomers (22DMB and 23DMB) was observed for UiO-66, which was attributed to the higher packing density of the shorter molecules. nHEX is the least retained hexane isomers due to its longer linear chain, which does not fit into small cavities of UiO-66. Furthermore, the adsorption hierarchy of hexane isomers was opposite to that of the typical adsorbents and depends on the temperature and pressure [92]. For the xylene isomers, the adsorption of bulkier o-xylene was preferred over the other isomers. Moreira et al. has also observed the reverse shape selectivity of xylene isomers in UiO-66, which was even preserved in the UiO-66 tablets [93]. Both UiO-66 powder and tablets showed preferred adsorption for oxylene in the liquid phase. The xylene adsorption capacity of UiO-66 tablets decreased compared with powder, but the selectivity of o-xylene with respect to m-xylene (1.8 at $313 \mathrm{~K}$ ) and p-xylene (2.4 at $313 \mathrm{~K})$ did not significantly change with shaping.

\subsection{Adsorption and separation properties of densified HKUST-1}

Another interesting MOF with a wide range of applications in gas adsorption [94-97], separation [98, 99], and catalysis $[32,33]$ is $\mathrm{Cu}_{3}(\mathrm{BTC})_{2}$ (HKUST-1), which was first reported by Chui et al. [100]. $\mathrm{Cu}_{2}$ metal clusters are linked by carboxylate groups to form a paddle-wheel unit in a cubic network of HKUST-1, which exhibits excellent thermal, structural stability and hydrophilic properties [32]. These properties of HKUST-1 are well studied for powder materials [1], but only a few reports available on densified materials [32, 33, 94, 95, 98, 99].

Kim et al. prepared HKUST-1 pellets with and without PVA binder [32]. In the binder-free method, HKUST-1 powder was mechanically pressed using an IR press in the pressure range of 25-340 atm and pellets with $1 \mathrm{~cm}^{2}$ width and $0.1 \mathrm{~cm}$ thickness were obtained. The pellets prepared with PVA binder retained their crystalline structure with some decrease in the intensity 
of XRD peaks compared with the powder, whereas the binder-free pellets pressed at a pressure higher than 100 atm showed a partial collapse in the crystal structure. The BET surface area of the pellet with PVA binder decreased by $45 \%$ compared with that of powder $\left(1737 \mathrm{~m}^{2} / \mathrm{g}\right)$; however the samples pressed at 25 and 50 atm with no binder showed relatively less reduction about $35 \%$ and $42 \%$, respectively. The total pore volume of both with binder and binder-free HKUST-1 pellets followed the same trend. Due to the higher mechanical strength compared to binder free pellets, water vapor and $\mathrm{CO}_{2}$ adsorption and catalysis studies were carried out only on the pellets prepared with a binder. The pellets exhibited a lower water adsorption capacity compared with powder, but both forms of HKUST-1 showed better performance in water uptake compared with Zeolite $13 \mathrm{X}$ and activated carbon as shown in Fig. 5(a) [32]. The $\mathrm{CO}_{2}$ adsorption isotherms at 273 and $298 \mathrm{~K}$ for HKUST-1 powder and pellets are shown in Fig. 5(b) [32]. The powder showed a significantly higher $\mathrm{CO}_{2}$ adsorption $(218 \mathrm{mg} / \mathrm{g}$ at $298 \mathrm{~K})$ compared with pellet $(129 \mathrm{mg} / \mathrm{g}$ at $298 \mathrm{~K})$ at both temperatures. Moreover, the $\mathrm{CO}_{2}$ saturation capacity of HKUST-1 powder and pellets were 38.3 and $21.4 \mathrm{mg} / \mathrm{g}$, respectively. However, the pellet is concluded as the preferred form for $\mathrm{CO}_{2}$ adsorption due to their high thermal stability, mechanical strength and reduced pressure drop despite the lower breakthrough capacity. Kim et al. also tested the catalytic properties of HKUST-1 in the liquid phase oxidation reaction of tetralin, wherein powder showed a better performance compared with pellets. The tetralin conversion at $353 \mathrm{~K}$ over HKUST-1 powder with, without, and after filtering the catalyst is shown in Fig. 5(c) [32]. The powder showed a tetralin conversion of $52 \%$ compared with $38 \%$ conversion of pellet, which was attributed to the pore diffusion limitations in the pellets.

A systematic investigation was carried out by Peterson et al. to understand the effects of pelletization pressure on the physical and chemical properties of HKUST-1 [95]. HKUST-1 has been considered as an excellent adsorbent of ammonia $\left(\mathrm{NH}_{3}\right)$; hence the impact of densification on the $\mathrm{NH}_{3}$ adsorption properties was specifically studied. The pellets with different applied pressures of 1000 and 10000 psi were prepared using a Carver Press. During the pelletization process, two grams of HKUST-1 powder was loaded into a $35 \mathrm{~mm}$ die and pressed for 1 minute at respective pressures inside a sealed plastic bag within a glove box to avoid any detrimental effects on the crystalline structure and porosity due to the moisture. The powder pressed at 1000 psi did not form a full pellet indicating the need of pelletization pressure $>1000$ psi to complete the densification process. The pellets were broken into smaller pieces using a mortar and pestle 
before the characterization. The crystalline structure of pellets did not deteriorate up to $10000 \mathrm{psi}$ of applied pressure according to the XRD results.. HKUST-1 powder and pellets exhibited identical Fourier transform infrared spectroscopy (FTIR) spectra indicating no chemical changes due to the pelletization. However, the BET surface area and pore volume of HKUST-1 decreased with the pelletization by about $38 \%$ and $19 \%$, respectively for the pellet pressed at 1000 psi compared with that of powder. This reduction in surface area and pore volume was more pronounced at the applied pressure of 10000 psi (47\% and 31\%, respectively). These pellets pressed at 1000 and 10000 psi were also tested for $\mathrm{NH}_{3}$ removal applications. More importantly, $\mathrm{NH}_{3}$ breakthrough testing showed consistent $\mathrm{NH}_{3}$ loading of $7.2 \mathrm{mmol} / \mathrm{g}$ for both powder and pellets indicating the excellent $\mathrm{NH}_{3}$ removal capability of HKUST-1 [95]. These results conclude that the pelletization did not degrade the $\mathrm{NH}_{3}$ removal capability of HKUST-1 due to the availability of active sites for ammonia sorption despite the decrease in surface area and pore volume.

The HKUST-1 pellets have also been tested for the removal of $\mathrm{Xe}$ and $\mathrm{Kr}$ from air [99]. To form the pellets, HKUST-1 powder was pressed into a disk at $12 \mathrm{MPa}$ for $5 \mathrm{~min}$ with no binder and the disk was broken and sieved to smaller pellets for the characterization. HKUST-1 pellets showed the BET surface area of $1252 \mathrm{~m}^{2} / \mathrm{g}$, which was slightly lower than that of powder. These pellets were then packed in an adsorption bed for the $\mathrm{Xe} / \mathrm{Kr}$ breakthrough experiments in pure $\mathrm{Xe}$ and $\mathrm{Kr}$ and mixtures of two gases with various compositions. HKUST-1 pellets showed high adsorption capacities for $\mathrm{Xe}$ and $\mathrm{Kr}$ and good selectivity to separate $\mathrm{Xe}$ and $\mathrm{Kr}$ from air even at ppm level concentrations. The Xe/Kr selectivity of HKUST-1 pellets in a mixture with 20:80\% ratio of $\mathrm{Xe}$ to $\mathrm{Kr}$ was 2.6. They showed $\mathrm{Xe}$ and $\mathrm{Kr}$ capacities of 8.5 and $2 \mathrm{mmol} / \mathrm{kg}$, respectively at $25^{\circ} \mathrm{C}$. The performance of HKUST-1 was comparable with benchmark activated carbon and also compared to another densified MOF (Ni/DOBDC), which showed even higher selectivity. According to the authors, this was the first time that MOFs were used to separate ppm level Xe from $\mathrm{Kr}$ mixtures in air [99].

Another emerging application of densified HKUST-1 is fast and efficient HPLC separation of ethylbenzene and styrene [98]. The HKUST-1 monolith showed the characteristic XRD pattern of HKUST-1, a surface area of $1240 \mathrm{~m}^{2} / \mathrm{g}$, and a micropore volume of $0.561 \mathrm{~cm}^{3} / \mathrm{g}$. The liquid chromatography separation is generally carried out by packing the material in a column, which 
often leads to low column efficiency for MOF particles. To avoid this issue, monolithic structure of HKUST-1 can be fitted into the column. The HKUST-1 monolithic column showed the separation of ethylbenzene and styrene within 2 min compared with 10 min observed for HKUST-1 particles packed column. This fast separation was attributed to the enhanced mass transport due to the highly interconnected macropores in the monolith [98]. Moreover, the monolithic column showed a high stability even after the operation of 6 weeks.

\subsection{Densification of flexible MOFs (MIL-53) for $\mathrm{CH}_{4} / \mathrm{CO}_{2}$ separation}

MIL-53 is a prototypical breathing type flexible $\mathrm{MOF}$ with $\mathrm{MO}_{4}(\mathrm{OH})_{2}[\mathrm{M}=\mathrm{Al}, \mathrm{Fe}, \mathrm{Cr}$, In, etc. $]$ octahedral metal clusters and BDC linkers [101]. MIL-53 has been extensively studied due to its flexible nature and adaptability of different metal clusters mainly $\mathrm{Cr}$ and $\mathrm{Al}$ specifically for applications in hydrocarbon/ $\mathrm{CO}_{2}$ adsorption and separation $[39,59,60,102,103]$. Thus, the pelletization has been employed to see whether it can improve the adsorption and separation properties of MIL-53. Heymans et al. carried out adsorption and separation studies of $\mathrm{CH}_{4}, \mathrm{H}_{2} \mathrm{~S}$, and $\mathrm{CO}_{2}$ on commercial MIL-53(Al) powder and pellets (Basolite A100) purchased from BASF [60]. As expected, powder form showed higher BET surface area $\left(829.9 \mathrm{~m}^{2} / \mathrm{g}\right)$ and total pore volume $\left(0.549 \mathrm{~cm}^{3} / \mathrm{g}\right)$ compared with pellets $\left(601.4 \mathrm{~m}^{2} / \mathrm{g}\right.$ and $0.398 \mathrm{~cm}^{3} / \mathrm{g}$, respectively). Adsorption isotherms of $\mathrm{CH}_{4}, \mathrm{H}_{2} \mathrm{~S}$, and $\mathrm{CO}_{2}$ at $303 \mathrm{~K}$ are shown in Fig. 6(a), which illustrate the higher adsorption capacities of $\mathrm{H}_{2} \mathrm{~S}$ followed by $\mathrm{CO}_{2}$ and $\mathrm{CH}_{4}$ in both powder and MIL-53(Al) pellets. Pellets have exhibited smaller adsorption capacities compared with powder for each adsorbent. However, the $\mathrm{CH}_{4} / \mathrm{CO}_{2}$ and $\mathrm{CH}_{4} / \mathrm{H}_{2} \mathrm{~S}$ separation properties are similar with high selectivity values for both powder and pellets [60]. The $\mathrm{CH}_{4} / \mathrm{CO}_{2}$ and $\mathrm{CH}_{4} / \mathrm{H}_{2} \mathrm{~S}$ separation factors are about 6.5-7 and 23-34, respectively. Furthermore, Finsy et al. studied the adsorptive separation of $\mathrm{CH}_{4} / \mathrm{CO}_{2}$ for MIL-53(Al) pellets prepared using a PVA binder [39]. These pellets showed an average separate factor of 7 , which is comparable with the value obtained by Heymans et al. for commercial MIL-53(Al) pellets [60]. The high $\mathrm{CH}_{4} / \mathrm{CO}_{2}$ separation factor is a very important conclusion of these studies since it is necessary to use MIL-53(Al) pellets for industrial applications.

Kapteijn's group has made an effort to enhance the $\mathrm{CH}_{4} / \mathrm{CO}_{2}$ separation factor in MIL-53(Al) by replacing the terephthalic acid flexible linker with 2-amino terephthalic acid to form $\mathrm{NH}_{2}$-MIL53(Al) $[58,103]$. They have reported orders of magnitude enhancement (almost infinite) in 
$\mathrm{CH}_{4} / \mathrm{CO}_{2}$ separation factor for $\mathrm{NH}_{2}-\mathrm{MIL}-53(\mathrm{Al})$ compared with MIL-53(Al) at 1 bar; however the origin of the enhancement was not clear at the time of experiments [58]. Thus, Stavitski et al. carried out an experimental work combined with density functional theory (DFT) calculations to find the origin of this enhancement [103]. The $\mathrm{NH}_{2}-\mathrm{MIL}-53(\mathrm{Al})$ pellets were prepared by pressing the powder to a solid disk followed by sieving to the desired particle size $(500-630 \mu \mathrm{m})$ for gas separation experiments, but no systematic study was done to understand the effect of pelletization pressure on the properties of $\mathrm{NH}_{2}-\mathrm{MIL}-53(\mathrm{Al})$. Adsorption isotherms of $\mathrm{H}_{2}, \mathrm{~N}_{2}$, $\mathrm{CH}_{4}$, and $\mathrm{CO}_{2}$ at $283 \mathrm{~K}$ for $\mathrm{NH}_{2}-\mathrm{MIL}-53(\mathrm{Al})$ pellets are shown in Fig. 6(b), which indicate a two-step isotherm of $\mathrm{CO}_{2}$ and discontinuity in $\mathrm{CH}_{4}$ isotherm around 5 bar as observed for MIL53(Al) [60]. Furthermore, there was no detectable adsorption of $\mathrm{H}_{2}$ or $\mathrm{N}_{2}$ in the measured pressure range. These results show a higher $\mathrm{CO}_{2} / \mathrm{CH}_{4}$ separation factor at pressures above 10 bar for $\mathrm{NH}_{2}$-MIL-53(Al) pellets compared with MIL-53(Al) as observed by Couck et al. [58], which was attributed to specific flexibility of $\mathrm{NH}_{2}-\mathrm{MIL}-53(\mathrm{Al})$ [103]. This specific flexibility ensures a smoother pore size increase with the increase in $\mathrm{CO}_{2}$ pressure, resulting in enhanced $\mathrm{CO}_{2}$ capture. Stavitski et al. further concluded that the enhanced $\mathrm{CO}_{2}$ adsorption and $\mathrm{CH}_{4} / \mathrm{CO}_{2}$ separation is governed by the formation of narrow pore polymorph in $\mathrm{NH}_{2}$-MIL-53(Al) after the solvent removal. Moreover, the weak chemical interactions between $\mathrm{NH}_{2}-\mathrm{MIL}-53(\mathrm{Al})$ and $\mathrm{CO}_{2}$ assured the full regeneration of the adsorbent within minutes, which is very important in practical applications.

\subsection{Densified MIL-101(Cr) for adsorption and separation}

MIL-101(Cr) is a very stable MOF consisted with trimeric Cr octahedral clusters connected by terephthalate ligands to form supertetrahedral building units [104]. It has an excellent chemical stability, high stability against moisture, high surface area, and mesoporous pores. These properties lead to various applications in hydrogen storage [34, 52, 54, 105], water and acidic gas adsorption [56, 106-108], and chromatography [109, 110]. MIL-101 (Cr) has also been densified as monoliths with high pellet density for the above applications [34, 52, 54, 56, 108, 109]. Ardelean et al. synthesized MIL-101(Cr) monoliths with different densities using a manual hydraulic press with the applied pressure of 30-120 MPa to study their hydrogen adsorption properties [34]. The crystalline structure of MIL-101(Cr) was preserved with densification up to a pellet density of $0.47 \mathrm{~g} / \mathrm{cm}^{3}$ as observed by the XRD patterns shown in Fig. 7(a); however the 
pellets with densities higher than the crystal density $\left(0.44 \mathrm{~g} / \mathrm{cm}^{3}\right)$ showed some modifications in the peak intensities. MIL-101(Cr) powder with a density of $0.19 \mathrm{~g} / \mathrm{cm}^{3}$ showed BET surface area of $3623 \mathrm{~m}^{2} / \mathrm{g}$ and total pore volume of $1.75 \mathrm{~cm}^{3} / \mathrm{g}$. The surface area and pore volume of monoliths gradually decreased to $2602 \mathrm{~m}^{2} / \mathrm{g}$ and $1.27 \mathrm{~cm}^{3} / \mathrm{g}$, respectively with the increasing density up to $0.47 \mathrm{~g} / \mathrm{cm}^{3}$, where it showed a sharp dip as shown in Fig. 7(b) [34]. The total excess $\mathrm{H}_{2}$ adsorption decreased with the increasing pellet density possibly due to the unavailability of some adsorption sites, which is also associated with the reduced surface area and micropore volume. Specifically, MIL-101(Cr) monoliths exhibited a total volumetric $\mathrm{H}_{2}$ storage capacity of $40 \mathrm{~g} / \mathrm{L}$ at $8 \mathrm{MPa}$ and $77 \mathrm{~K}$ for the pellets with densities of $0.46-0.48 \mathrm{~g} / \mathrm{cm}^{3}$ [34]. This optimum total volumetric $\mathrm{H}_{2}$ uptake of MIL-101(Cr) pellets is also comparable with that of densified MOF-5 and MOF-177 (42 g/L) and reached the DOE target for volumetric $\mathrm{H}_{2}$ storage capacity. Blanita et al. have also observed a similar volumetric $\mathrm{H}_{2}$ uptake ( $\left.40 \mathrm{~g} / \mathrm{L}\right)$ for MIL-101(Cr) pellets with densities of $0.4-0.467 \mathrm{~g} / \mathrm{cm}^{3}$ at $77 \mathrm{~K}$ and 100 bar and it is about $11 \%$ increase compared with that of powder [52]. It also showed a total gravimetric $\mathrm{H}_{2}$ uptake of $\sim 7$ $\mathrm{wt} \%$ at $77 \mathrm{~K}$, which is well above the DOE target (5.5 wt\%). These optimum values for volumetric and gravimetric $\mathrm{H}_{2}$ uptake were obtained with the expense of only $5 \%$ decrease in BET surface area, micropore volume, and total pore volume compared with MIL-101(Cr) powder [52].

As an alternative to $\mathrm{H}_{2}$ compressed at high pressures, low pressure liquid $\mathrm{H}_{2}$ storage systems with high density and low cost can be used at cryogenic temperatures (around $20 \mathrm{~K}$ ). However, boil-off loss is a major drawback in liquid $\mathrm{H}_{2}$ storage systems. Thus, there was an effort to avoid boil-off losses by integrating cryo-adsorption of $\mathrm{H}_{2}$ in MIL-101 $(\mathrm{Cr})$ monoliths at $20 \mathrm{~K}$. Oh and co-workers investigated the optimum $\mathrm{H}_{2}$ storage capacity of MIL-101(Cr) pellets at $20 \mathrm{~K}$ [54]. The BET surface area of the pellets $\left(2745 \mathrm{~m}^{2} / \mathrm{g}\right)$ was lower than that of powder $\left(3414 \mathrm{~m}^{2} / \mathrm{g}\right)$. They have observed maximum gravimetric and volumetric excess $\mathrm{H}_{2}$ adsorptions of $9.6 \mathrm{wt} \%$ and $42.3 \mathrm{~g} / \mathrm{L}$, respectively at $20 \mathrm{~K}$ for MIL-101(Cr) pellets, which passed the DOE 2017 targets $(5.5$ $\mathrm{wt} \%$ and $40 \mathrm{~g} / \mathrm{L}$ ) for hydrogen storage. Furthermore, the excess gravimetric $\mathrm{H}_{2}$ uptake, surface area, and pore volume were only reduced by $20 \%$ for the MIL-101(Cr) pellets compared with powder. It is concluded that the cryo-adsorption of $\mathrm{H}_{2}$ by MIL-101(Cr) at $20 \mathrm{~K}$ could be 
beneficial for industrial applications in comparison to liquid $\mathrm{H}_{2}$ due to their larger temperature window to operate without boil-off losses.

Hong et al. tested the $\mathrm{CO}_{2}$ adsorption properties of MIL-101(Cr) pellets prepared by paste extrusion technique [56] . Bentonite clay was used as a binder and mixed with MIL-101(Cr) powder and water to form a paste at room temperature. The matured paste was then extruded into monoliths on a single screw extruder and dried in a temperature controlled chamber at $10^{\circ} \mathrm{C}$ for several days. They were further fired in a kiln at $150^{\circ} \mathrm{C}$ for 33 hours to obtain strong and solid monoliths. XRD patterns of MIL-101(Cr) powder and monoliths unambiguously confirm that the crystalline structure is not disturbed during the preparation of monoliths. The pore properties of MIL-101(Cr) powder and monoliths were also studied using mercury intrusion porosimetry (MIP). The porosity of the as-synthesized monoliths was reduced by $14 \%$ compared with that of powder. Pure $\mathrm{CO}_{2}$ adsorption isotherms showed slightly lower $\mathrm{CO}_{2}$ adsorption capacity in monoliths compared with powder, which was attributed to the addition of binding agent (bentonite clay) [56]. MIL-101(Cr) has also shown good water adsorption properties and stability toward water up to $573 \mathrm{~K}$ [111]. Thus, water adsorption properties of MIL-101(Cr) monoliths prepared using resorcinol-formaldehyde xerogels as the binding agent were studied by Wickenheisser and co-workers [108]. The main objective of this study to utilize MIL101(Cr)/xerogel composite monoliths for heat transfer applications including thermally driven adsorption chillers and adsorption heat pumps. The XRD data confirmed the retention of crystallinity in MIL-101(Cr)/polymer composite compared to neat MOF; only some broadening of the peaks was observed. The scanning electron microscopy (SEM) images showed a well adherence between MIL-101(Cr) and xerogel polymer. The composite monoliths with 77 wt\% of MIL-101(Cr) showed BET surface area and pore volume of $2530 \mathrm{~m}^{2} / \mathrm{g}$ and $1.27 \mathrm{~cm}^{3} / \mathrm{g}$, respectively. It is only $17 \%$ and $12 \%$ reduction in surface area and pore volume, respectively compared with that in neat MIL-101(Cr). The monoliths with $77 \mathrm{wt} \%$ of MIL-101(Cr) also exhibited the maximum water adsorption $(0.79 \mathrm{~g} / \mathrm{g})$ among all composites at P.P $\mathrm{o}_{\mathrm{o}}^{-1}=0.5$, which is also higher than that of bulk MIL-101(Cr) $(0.57 \mathrm{~g} / \mathrm{g})$. The surface-area based water adsorption of all monoliths was also comparable to that of bulk MIL-101(Cr). Thus, MIL-101(Cr)/xerogel composite monoliths showed good potential for water adsorption applications [108]. 
MIL-101(Cr) pellets have also been used in another very important application; chromatographic separation of various analytes including xylene, cymene, chlorotoluene, aromatic acids, aromatic hydrocarbons, and bovine serum albumin (BSA) peptides [109]. Huang et al. developed a novel MOF-organic polymer (methacrylate monomers) composite monolith using MIL-101(Cr) for capillary electrochromatography (CEC) and nano-liquid chromatography (nano-LC) [109]. The composite monoliths were prepared using a 5 min microwave-assisted polymerization. A difference in surface morphologies was observed in SEM micrographs for MIL-101(Cr)-polymer monoliths compared with neat MIL-101(Cr) and neat polymer monoliths. XRD pattern of MIL101(Cr)-polymer monolith with $50 \mathrm{wt} \%$ of MIL-101(Cr) showed characteristic peaks of MIL101(Cr) with some changes in the peak intensities. Nitrogen adsorption/desorption isotherms confirmed the decrease in BET surface area of MIL-101(Cr)-polymer monolith to $732 \mathrm{~m}^{2} / \mathrm{g}$ compared with MIL-101(Cr) $\left(2938 \mathrm{~m}^{2} / \mathrm{g}\right)$, but both the samples showed a similar pore size distribution. Fourier transform infrared spectroscopy (FTIR) and SEM/energy dispersive spectroscopy (EDS) results further confirmed the homogeneous distribution of MIL-101(Cr) in

the MOF/polymer monolith. Following the materials characterization, CEC separation of xylene isomers by MIL-101(Cr)-polymer monoliths was studied. CEC results indicated baseline separations for para, meta, and ortho-xylene isomers using neat MIL-101 (Cr) and MOF/polymer monoliths, but no separation was observed for neat polymer monolith as shown in Fig. 8 [109]. The separation of isomers by these monoliths was further evaluated using chlorotoluene and cymene and the para, meta, and ortho-cymene isomers showed well-separated peaks in electrochromatograms at higher column lengths. The applications of MIL-101(Cr)-polymer monoliths were also extended to nano-LC separation of polycyclic aromatic hydrocarbons, aromatic acids, and BSA try-spin digested peptides. MIL-101(Cr)-polymer monoliths showed promising separation properties for all test analytes suggesting the adaptability of MOFs/polymer composites in chromatography applications [109].

\subsection{Densification of mechanically robust ZIF-8}

Zeolitic imidazolate frameworks (ZIFs) are considered as a sub-family of MOFs with metal clusters connected via imidazolate organic linkers $[112,113]$. ZIFs (ZIF-8 particularly) have significantly high thermal stability and as well as stability against humidity in addition to other unique MOF properties such as extremely high porosity and surface area [113], which makes 
them ideal candidates for gas adsorption [114-117], separation [118-122], and catalysis [123126]. Specifically, gas adsorption properties of ZIFs can be tuned by tailoring the linker, which is very important for gas storage applications [127, 128]. Among ZIF materials, ZIF-8 has attracted more attention in gas adsorption and separation due to the presence of large cavities connected by narrow windows in the sodalite type structure [129]. Despite being extremely stable, industrial applications of ZIF-8 are limited in powder form. Thus, shaping up these materials to desired forms is essential to avoid any pressure drops in gas columns due to powder compaction [65]. Thus, ZIF-8 has been densified in the form of pellets and monoliths and tested for various applications in gas adsorption, gas separation, and catalysis [33, 61-65].

Tian et al. reported the fabrication of mechanically and chemically robust ZIF-8 monoliths under ambient conditions without using binders [65]. Four different ZIF-8 monolith samples were synthesized in this study using various post-treatment methods including drying at $100{ }^{\circ} \mathrm{C}$ overnight in a vacuum oven (ZIF-8HT), drying at room temperature overnight (ZIF-8LT), drying at room temperature followed by high temperature treatment (ZIF-8LT-HT), and washing extensively with ethanol (ZIF-8ER). ZIF-8HT sample was easily disaggregated into powder form, but ZIF-8LT and ZIF-8LT-HT samples retained their monolithic structure. The different surface morphologies of these samples were also evidenced from SEM images as shown in Fig. 9(a) [65], wherein the ZIF-8LT and ZIF-8LT-HT samples exhibit relatively flat surfaces in contrast to meso-and macro-porous ZIF-8HT surface. However, the crystalline structures of all four ZIF-8 samples were identical to that of ZIF-8 powder according to the XRD patterns shown in Fig. 9(b) [65]. The fabricated monoliths showed higher mechanical strength than ZIF-8 single crystals and very high bulk densities while maintaining their porosity. The BET surface area of monoliths measured using $\mathrm{N}_{2}$ adsorption at $77 \mathrm{~K}$ is in the range of $1359-1423 \mathrm{~m}^{2} / \mathrm{g}$, which is comparable with that of ZIF-8 powder $\left(1300-1600 \mathrm{~m}^{2} / \mathrm{g}\right)$. ZIF-8LT-HT showed the highest surface area and ZIF-8ER sample has the best mechanical strength. Thus, the slow drying process and extended reactions were recommended to obtain ZIF-8 monoliths with better adsorption and mechanical properties. The volumetric capacity of ZIF-8 monoliths was also measured using mercury porosimetry, which showed high bulk densities from $1-1.2 \mathrm{~g} / \mathrm{cm}^{3}$ for monoliths compared with ZIF-8 powder $\left(0.35 \mathrm{~g} / \mathrm{cm}^{3}\right)$. In conclusion, better mechanical properties and higher volumetric adsorption capacity make ZIF-8 monoliths ideal for industrial applications [65]. 
Nuclear waste management is a critical issue in clean and safe nuclear energy production [130, 131]. Specifically, the capture of volatile radionuclides including iodine $\left(I_{2}\right)$ is a greater challenge [132]. Porous absorbents like silver-exchanged zeolites have been used to trap $\mathrm{I}_{2}$, but they have limited adsorption capacities due to the smaller surface area [133]. Thus, MOFs have emerged as high capacity $I_{2}$ adsorbents due to their large surface area $[64,134,135]$. However, MOFs have shown reversible uptake or loss of $\mathrm{I}_{2}$ at moderate temperatures in most of the studies [135]. Recently, Sava et al. investigated ZIF-8 powder and pellets for $\mathrm{I}_{2}$ capture [64]. They observed efficient trapping of $\mathrm{I}_{2}$ with no release of $\mathrm{I}_{2}$ up to $\sim 575 \mathrm{~K}$ for ZIF-8 and the highest $\mathrm{I}_{2}$ uptake of $125 \mathrm{wt}$ \% loading reported for any MOF. The crystallinity of ZIF-8 powder was retained up to $70 \mathrm{wt} . \%$ of $\mathrm{I}_{2}$ loading and it confirmed the structural stability of ZIF-8 upon $\mathrm{I}_{2}$ loading. To explore the possibility of using ZIF-8 for $\mathrm{I}_{2}$ capture in nuclear energy applications, binder-free ZIF-8 pellets were also prepared by extrusion [64]. A homogeneous paste with 1g of ZIF-8 powder and $2 \mathrm{ml}$ of water was extruded to cylindrical pellets of $\sim 3 \mathrm{~mm}$ in diameter and 10 $\mathrm{mm}$ in length. $\mathrm{N}_{2}$ adsorption isotherms at $77 \mathrm{~K}$ confirmed no significant change in the porosity of extruded ZIF-8 compared with powder form. In addition, ZIF-8 pellets showed slightly higher BET surface area $\left(1837 \mathrm{~m}^{2} / \mathrm{g}\right)$ than powder $\left(1766 \mathrm{~m}^{2} / \mathrm{g}\right)$. The crystalline structure of ZIF-8 was also maintained during the extrusion as confirmed by XRD patterns. The $\mathrm{I}_{2}$ uptake of pellets was also comparable with ZIF-8 powder. It was concluded that ZIF-8 in both powder and pellet forms exhibits excellent properties for capture and interim storage of $\mathrm{I}_{2}$. However, the authors recommended further assessment of the properties of ZIF-8 for long term storage of $I_{2}$ [64].

ZIF-8 pellets have also been tested for the separation of xylene isomers and bioalcohols.[61, 63] ZIF-8 has shown a good separation of hexane isomers due to its molecular sieving properties.[136, 137] Peralta et al. studied the adsorption and separation of xylene isomers by ZIF-8.[63] Xylene $\left(\mathrm{C}_{8} \mathrm{H}_{10}\right)$ is an aromatic hydrocarbon with a benzene ring and two methyl groups, which is a major petrochemical. In this study, ZIF-8 pellets with diameters from 300 to $500 \mu \mathrm{m}$ were used for xylene isomer separation experiments. ZIF-8 pellets exhibited a good separation between ortho, meta, and para-xylene isomers via a molecular sieving mechanism despite the small pore aperture. The highest adsorption was observed for para-xylene which easily diffuses through the ZIF-8 pore openings due to its smaller kinetic diameter, whereas ortho-xylene showed the least adsorption by ZIF-8 pellets. The ZIF-8 pellets showed better separation selectivity for xylene isomers in gas phase compared with that in liquid phase [63]. 
Bioalcohols including bioethanol and biobutanol are promising alternative energy sources to fossil fuels [138, 139]. Specifically, biobutanol with excellent fuel properties is produced by the fermentation of biomass, which needs to be separated from its aqueous medium for commercial production [140]. Thus, the separation of biobutonal is very important and extensively investigated using various methods [141-143]. Cousin et al. have studied the biobutanol separation of ZIF-8 pellets prepared by mechanical pressing of powder, followed by crushing and sieving [61]. ZIF-8 showed the largest butanol adsorption compared with active carbon and silicalite. A mixture of water, ethanol, acetone, and butanol was efficiently separated by ZIF-8 pellets indicating ZIF-8 is a highly efficient adsorbent for biobutanol purification [61].

ZIF-8 has also been utilized as a catalyst for transesterification of vegetable oils [33, 144]. Bazer-Bachi et al. pelletized ZIF-8 under different forces without a binder [33]. These samples did not exhibit a significant change in the surface morphology as observed by SEM. In contrast, the crystallinity of pellets was decreased with the increased pelletization pressure resulting only $86 \%$ of crystallinity for the sample pressed at $0.1 \mathrm{~g} / 18 \mathrm{kN}$ relative to powder. The BET surface area of the same pellet was also reduced by $11 \%$ compared with the native powder. For the catalysis in vegetable oil transesterification, ZIF-8 pellets were prepared with a binder to achieve the required mechanical strength to use them in catalysis laboratory scale reactor. The surface area of these samples also followed the same trend observed in the pellets with no binder with the increasing applied pressure. According to the catalysis results, catalytic activity of pelletized ZIF-8 was comparable with that of ZIF-8 powder. These results further demonstrated the feasibility of using densified ZIF-8 in industrial applications [33].

\section{Conclusions and future perspectives}

The last decade has seen an exponential rise in the publications and citations of MOFs with more than 20000 different MOFs being synthesized. However, the commercial applications of MOFs are still restricted due to their limited robustness against water, low density, low volumetric adsorption, and poor thermal conductivity in as synthesized powder form. A comprehensive understanding on stability and performance is required against the typical operating conditions to realize these materials for commercial applications. To meet this goal, this review presents a 
detailed survey of MOF properties and quantifies the stability of MOFs as a function of humidity level, exposure time, and pellet density. Based on the recent developments it does appear that the new densification strategies developed by researchers show significant improvement in thermal and mechanical properties of MOFs to meet various industrial requirements. Specifically, the volumetric adsorption and stability in humid environments of MOFs were significantly improved with the densification. The increase in the volumetric density of densified MOFs leads to the enhanced volumetric adsorption, which is very important for gas storage applications. MOF powders showed instability towards water due to the irreversible structural changes under humid conditions. These structural changes were suppressed in densified MOFs due to reduced water permeation into the pellets, which leads to better kinetic stability in humid environments. Thus, the densification of MOFs in the form of pellets, beads, monoliths, or coatings has been identified as a necessary step for technological leap and industrial use. In this review, we recapitulated the efforts carried out in last five years on densification of MOFs to improve their adsorption, thermal, and mechanical properties. The detailed summary in Table 2 clearly illustrates the properties including crystallinity, adsorption capacity, separation, and catalytic properties, porosity, and surface area of various MOFs densified in the form of pellets or monoliths with different pellet densities. In our survey, the experimental conditions were very much dispersed, thus the properties varied significantly. Despite the dispersed experimental conditions and results, the following conclusions can be broadly drawn on densified MOFs.

1. Mechanical strength, volumetric adsorption, and stability of MOFs in humid and reactive environments are significantly enhanced with the densification of MOFs. Specifically, volumetric hydrogen storage capacity of densified MOF- 5 with a pellet density of 0.5 $\mathrm{g} / \mathrm{cm}^{3}$ is increased by $350 \%$ relative to powder.

2. Densification of MOF-5 into pellets slows down its degradation significantly, offering an attractive alternate strategy to improve stability of MOFs.

3. Acidic gas and liquid chromatography separation are also improved with the densification.

4. The thermal conductivity of densified MOFs can be improved by the addition of binders such as graphite. 
5. Surface area, pore volume, and gravimetric adsorption decreased with the increasing pellet density. This decrease is about $10-20 \%$ at a pellet density of $0.5 \mathrm{~g} / \mathrm{cm}^{3}$ relative to MOF powder.

6. Crystallinity of densified MOFs can be reduced with the increasing pelletization pressure; MOFs become amorphous at a certain critical pellet density, which is about $0.5 \mathrm{~g} / \mathrm{cm}^{3}$ for most of the studied materials.

The use of binders such as ENG may partly protect MOF deformation or amorphization during mechanical compaction, resulting in overall improved mechanical stability while retaining adsorption capacities. Finally, at a given pellet density, it's all about the compromise between volumetric and gravimetric adsorption capacities. For most of the densified MOFs, the optimum pellet density is about $0.5 \mathrm{~g} / \mathrm{cm}^{3}$, which exhibits the highest volumetric adsorption, chemical stability, and mechanical strength without significantly compromising the crystallinity, surface area, pore volume, and gravimetric adsorption. Thus, we conclude that the structural, physical, mechanical, thermal, and adsorption properties of densified MOFs can be precisely tailored by tuning the pellet density of the shaped structures. Simple densification strategies will unlock the potential of MOFs for industrial applications and play a key role in emerging applications.

\section{Acknowledgements}

The U.S. Department of Energy (DOE), Office of Fossil Energy, supported this work. The Pacific Northwest National Laboratory (PNNL) is operated for DOE by Battelle Memorial Institute under Contract\# DE-AC06-76RLO-1830. 


\begin{tabular}{|c|c|c|c|c|c|}
\hline Type of MOF & Crystal structure & $\begin{array}{l}\text { Metal } \\
\text { cluster }\end{array}$ & Organic linker & Applications & Ref. \\
\hline MOF-5 & & {$\left[\mathrm{Zn}_{4} \mathrm{O}\right]^{6+}$} & $\begin{array}{l}\text { 1,4-benzene } \\
\text { dicarboxlate }\end{array}$ & $\begin{array}{l}\text { Hydrogen storage } \\
\text { Methane adsorption }\end{array}$ & $\begin{array}{c}{[31,} \\
45,48,\end{array}$ \\
\hline & & & $(\mathrm{BDC})$ & VOC sensing & $49,82]$ \\
\hline UiO-66 & & $\mathrm{Zr}_{6} \mathrm{O}_{4}(\mathrm{OH})_{4}$ & $\mathrm{BDC}$ & $\begin{array}{c}\mathrm{CO}_{2} \text { adsorption } \\
\text { Toxic gas removal }\end{array}$ & $\begin{array}{c}{[57} \\
67,88]\end{array}$ \\
\hline & & & & $\begin{array}{c}\text { Catalysis } \\
\text { Liquid phase separation }\end{array}$ & \\
\hline $\mathrm{Cu}_{3}(\mathrm{BTC})_{2}$ & & $\mathrm{Cu}_{2}$ & Carboxlate & $\begin{array}{l}\text { Water and } \mathrm{CO}_{2} \text { adsorption } \\
\text { Toxic gas removal }\end{array}$ & $\begin{array}{l}{[32,} \\
33,95,\end{array}$ \\
\hline & & & & Liquid phase separation & $98]$ \\
\hline ZIF-8 & & $\mathrm{Zn}$ & $\begin{array}{l}\text { 2-methyl } \\
\text { imidazole }\end{array}$ & $\begin{array}{c}\text { Catalysis } \\
\text { Iodine storage }\end{array}$ & $\begin{array}{c}{[33,} \\
61,63-\end{array}$ \\
\hline & & & & $\begin{array}{c}\mathrm{H}_{2} \mathrm{~S} \text { adsorption } \\
\text { Separation of organics }\end{array}$ & 65] \\
\hline MIL-53 & & $\begin{array}{l}\mathrm{MO}_{4}(\mathrm{OH})_{2} \\
{[\mathrm{M}=\mathrm{Al}, \mathrm{Fe}}\end{array}$ & $\mathrm{BDC}$ & $\begin{array}{l}\text { Acidic gas separation } \\
\text { Hydrocarbon separation }\end{array}$ & $\begin{array}{l}{[58,} \\
60,\end{array}$ \\
\hline \multirow{3}{*}{ MIL-101 (Cr) } & & Cr, In, etc.] & \multirow[b]{2}{*}{ Terephthalate } & \multirow[b]{2}{*}{$\begin{array}{c}\text { Hydrogen storage } \\
\text { Water and } \mathrm{CO}_{2} \text { adsorption }\end{array}$} & 103] \\
\hline & & $\mathrm{Cr}$ & & & $\begin{array}{c}{[34,} \\
54,56,\end{array}$ \\
\hline & & & & Liquid phase separation & $\begin{array}{l}108, \\
109]\end{array}$ \\
\hline
\end{tabular}


MOF-177

$\mathrm{Zn}_{4} \mathrm{O}$

Benzenetri-

Hydrogen storage

$[53$,

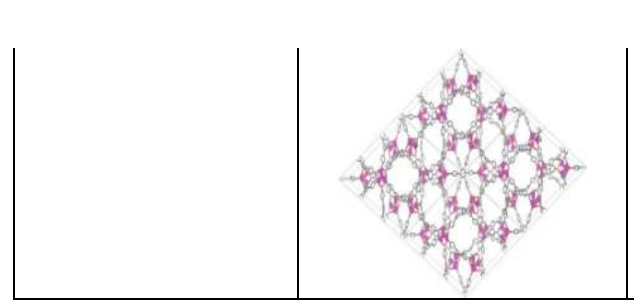
benozate

Table 1. The crystal structures, metal clusters, organic linkers, and specific applications of various types of densified MOFs. 


\begin{tabular}{|c|c|c|c|c|c|c|c|}
\hline Type of MOF & Reference & $\begin{array}{l}\text { Method of } \\
\text { densification }\end{array}$ & $\begin{array}{l}\text { Pellatization } \\
\text { pressure }\end{array}$ & $\begin{array}{l}\text { Crystallinity } \\
\text { (XRD) }\end{array}$ & $\begin{array}{l}\text { Surface area - } \\
\text { BET }\left(\mathrm{m}^{2} / \mathrm{g}\right) \\
\text { (powder) }\end{array}$ & $\begin{array}{c}\text { Pore volume } \\
\left(\mathrm{cm}^{3} / \mathrm{g}\right) \text { (powder) }\end{array}$ & Properties \\
\hline \multirow[t]{2}{*}{ MOF-5 } & Jia et al. [31] & Mechanical pressing & $0.5-2 \mathrm{MPa}$ & & $\begin{array}{l}1450 @ 2 \mathrm{MPa} \\
(2777)\end{array}$ & & $\mathrm{CH}_{4}$ volumetric storage is $81 \mathrm{~V}(\mathrm{STP}) / \mathrm{V}$ at $3.69 \mathrm{Mpa}$ at $1 \mathrm{MPa}$ \\
\hline & Purewal et al. [49] & Mechanical pressing & $0-350 \mathrm{MPa}$ & $\begin{array}{l}\text { crystalline up to } \\
80 \mathrm{MPa}\end{array}$ & $\begin{array}{l}2265 @ 50 \mathrm{Mpa} \\
(2762)\end{array}$ & $\begin{array}{l}1.1 @ 50 \mathrm{Mpa} \\
(1.4)\end{array}$ & $\begin{array}{l}\text { Increase in volumetric } \mathrm{H}_{2} \text { uptake by a factor of } 3.5 \text { at } 50 \mathrm{MPa} \\
15 \% \text { decrease in gravimetric } \mathrm{H}_{2} \text { uptake @ } 50 \mathrm{MPa} \\
\text { Sample pressed at } 50 \mathrm{MPa} \text { (density of } 0.51 \mathrm{~g} / \mathrm{cm} 3 \text { ) has the } \\
\text { best properties }\end{array}$ \\
\hline $\begin{array}{l}\text { MOF-5/graphite } \\
\text { (ENG) }\end{array}$ & $\begin{array}{l}\text { Siegel et al. [45- } \\
48,50]\end{array}$ & $\begin{array}{l}\text { Mechanical/hydrolic } \\
\text { pressing }\end{array}$ & $0-350 \mathrm{MPa}$ & $\begin{array}{l}\text { comparable with } \\
\text { pure MOF } \\
\text { pellets }\end{array}$ & $\begin{array}{l}2623(5 \mathrm{wt} \% \\
\text { ENG)@ } 40 \mathrm{Mpa} \\
(2263)\end{array}$ & $\begin{array}{l}1.14(5 \mathrm{wt} \% \\
\text { ENG)@ } 40 \mathrm{Mpa} \\
(1.12)\end{array}$ & $\begin{array}{l}\text { Improved thermal conductivity (factor of } 3 \& 5 \text { ) for } 5 \& 10 \\
\text { wt } \% \text { ENG } \\
5-10 \mathrm{wt} \% \text { ENG added MOF-5 pellets pressed @ } 40 \mathrm{MPa} \\
\text { (density of } 0.5 \mathrm{~g} / \mathrm{cm} 3 \text { ) has the optimal properties } \\
\text { Thermal conductivity increased by } 20 \text { times with the } \\
\text { fabrication of alternative layers of ENG ( } 5 \mathrm{wt} \% \text { ) and MOF-5 } \\
\text { in the composite } \\
\text { Densification improved the stability of MOF- } 5 \text { by slowing } \\
\text { down the degradation in humid environments }\end{array}$ \\
\hline Zr-MOF & Ren et al. [145] & Granulation & & Crystalline & $674(1367)$ & $0.34(0.56)$ & $\mathrm{H}_{2}$ uptake (wt.\%) - 0.85 (1.54) \\
\hline \multirow[t]{2}{*}{ UiO-66 } & Peterson et al. [67] & Mechanical pressing & $\begin{array}{l}35-690 \\
\text { Мра }\end{array}$ & $\begin{array}{l}\text { Crystalline upto } \\
170 \mathrm{MPa}\end{array}$ & $\begin{array}{l}876 \text { at } 170 \mathrm{MPa} \\
(1182)\end{array}$ & $\begin{array}{l}0.44 \text { at } 170 \mathrm{Mpa} \\
(0.5)\end{array}$ & $\begin{array}{l}\mathrm{NH}_{3} \text { uptake }(\mathrm{mol} / \mathrm{Kg})-2.2 @ 170 \mathrm{MPa}(3.3) \\
\mathrm{CNCl} \text { uptake }(\mathrm{mol} / \mathrm{Kg})-2.7 @ 170 \mathrm{MPa}(4.1)\end{array}$ \\
\hline & Kim et al. [57] & Extrusion & & & $\begin{array}{l}1387 \text { - } \mathrm{UiO} 100 \mathrm{~L} \\
\text { glass reactor }\end{array}$ & & \\
\hline $\begin{array}{l}\text { UiO-66/polymer } \\
\text { monoliths }\end{array}$ & Fu et al. [88] & $\begin{array}{l}\text { Methacrylate } \\
\text { polymerization }\end{array}$ & & crystalline & $\begin{array}{l}321.4 \text { (UiO-66 - } \\
881.1)\end{array}$ & & Enhanced HPLC separation \\
\hline \multirow[t]{4}{*}{ CuBTC (HKUST-1) } & Peterson et al. [95] & Mechanical pressing & $7-70 \mathrm{MPa}$ & crystalline & $\begin{array}{l}892 \text { at } 70 \mathrm{MPa} \\
(1698)\end{array}$ & $\begin{array}{l}0.52 \text { at } 70 \mathrm{MPa} \\
(0.75)\end{array}$ & $\mathrm{NH}_{3}$ loading $(\mathrm{mmol} / \mathrm{g})-7.1 @ 70 \mathrm{MPa}(7.2)$ \\
\hline & \multirow[t]{2}{*}{ Kim et al. [32] } & Extrusion & & crystalline & $963(1737)$ & $0.41(0.72)$ & \\
\hline & & $\begin{array}{l}\text { Binder-free } \\
\text { mechanical pressing }\end{array}$ & $2.5-35 \mathrm{Mpa}$ & $\begin{array}{l}\text { crystalline (upto } \\
10 \mathrm{MPa} \text { ) }\end{array}$ & $\begin{array}{l}953 @ 10 \mathrm{Mpa} \\
(1737)\end{array}$ & $\begin{array}{l}0.41 @ 10 \mathrm{Mpa} \\
(0.72)\end{array}$ & $\begin{array}{l}\mathrm{CO}_{2} \text { and water adsorption decreased with pelletization } \\
\text { Water adsorption is better compared to Zeolite }\end{array}$ \\
\hline & $\begin{array}{l}\text { Bazer-Bachi et al. } \\
\text { [33] }\end{array}$ & Mechanical pressing & & $\begin{array}{l}\text { crystalline (upto } \\
200 \mathrm{MPa} \text { ) }\end{array}$ & $\begin{array}{l}1377 @ 40 \mathrm{MPa}, \\
(1897)\end{array}$ & & \\
\hline \multirow[t]{3}{*}{ MIL-53(Al) } & Finsy et al. [39] & Extrusion & & & & & Good $\mathrm{CO}_{2} / \mathrm{CH}_{4}$ separation (factor of 7) \\
\hline & $\begin{array}{l}\text { Heymans et al. } \\
{[60]}\end{array}$ & & & & $601.4(829.9)$ & $0.398(0.549)$ & $\begin{array}{l}\mathrm{CH}_{4} / \mathrm{CO}_{2} \text { and } \mathrm{CH}_{4} / \mathrm{H}_{2} \mathrm{~S} \text { separations are comparable with } \\
\text { powder }\end{array}$ \\
\hline & Ferreira et al. [59] & & & & & & good selectivity (about 4) between $\mathrm{CH}_{4}$ and $\mathrm{CO}_{2}$ \\
\hline NH2-MIL-53(In) & $\begin{array}{l}\text { Serra-Crespo et al. } \\
\text { [68] }\end{array}$ & & & $\begin{array}{l}\text { crystalline up to } \\
23 \mathrm{GPa}\end{array}$ & & & Showed higher resistance to amorphization \\
\hline
\end{tabular}




\begin{tabular}{|c|c|c|c|c|c|c|c|}
\hline \multirow[t]{2}{*}{ ZIF-8 } & $\begin{array}{l}\text { Bazer-Bachi et al. } \\
{[33]}\end{array}$ & Mechanical pressing & & $\begin{array}{l}96 \% \\
\text { crystallinity at } \\
400 \mathrm{Mpa}\end{array}$ & $\begin{array}{l}1420 @ 400 \mathrm{MPa} \\
(1433)\end{array}$ & & \\
\hline & Tian et al. [65] & Extrusion & & & $\begin{array}{l}1423(1300- \\
1600)\end{array}$ & 0.546 & \\
\hline \multirow[t]{2}{*}{ MOF-177 } & Dailly et al. [53] & & & & $2920(3965)$ & $1.22(1.67)$ & $\begin{array}{l}\text { Hydrogen storage capacity is comparable with compressed } \mathrm{H}_{2} \\
\text { gas }\end{array}$ \\
\hline & Zacharia et al. [55] & Mechanical pressing & & $\begin{array}{l}\text { crystalline up to } \\
\text { a density of } 0.43 \\
\mathrm{~g} / \mathrm{cm} 3\end{array}$ & $\begin{array}{l}3600 \text { at a density } \\
\text { of } 0.43 \mathrm{~g} / \mathrm{cm}^{3} \\
(4100)\end{array}$ & & $\begin{array}{l}\text { Total volumetric } \mathrm{H}_{2} \text { storage capacity of } 48 \mathrm{~g} / \mathrm{L} \text { at } 13 \mathrm{MPa} \text { and } \\
77 \mathrm{~K} \text { for pellets }\end{array}$ \\
\hline \multirow[t]{4}{*}{ MIL-101 (Cr) } & $\begin{array}{l}\text { Ardelean et al. } \\
{[34]}\end{array}$ & Hydrolic pressing & 0- $120 \mathrm{MPa}$ & $\begin{array}{l}\text { crystalline up to } \\
\text { a density of } 0.47 \\
\mathrm{~g} / \mathrm{cm}^{3}\end{array}$ & $\begin{array}{l}2602 \text { at a density } \\
\text { of } 0.47 \mathrm{~g} / \mathrm{cm}^{3} \\
(3623)\end{array}$ & $\begin{array}{l}1.27 \text { at a density } \\
\text { of } 0.47 \mathrm{~g} / \mathrm{cm}^{3} \\
(1.75)\end{array}$ & $\begin{array}{l}\text { Total volumetric } \mathrm{H}_{2} \text { storage capacity of } 40 \mathrm{~g} / \mathrm{L} \text { at } 8 \mathrm{Mpa} \text { and } \\
77 \mathrm{~K} \text { for pellets with a density of } 0.45-0.47 \mathrm{~g} / \mathrm{cm}^{3}\end{array}$ \\
\hline & Oh et al. [54] & & & & $2745(3414)$ & $1.5(1.9)$ & $\begin{array}{l}\text { Total volumetric } \mathrm{H}_{2} \text { storage capacity of } 42.3 \mathrm{~g} / \mathrm{L} \text { for pellets at } \\
20 \mathrm{~K}\end{array}$ \\
\hline & Blanita et al. [52] & Mechanical pressing & & & $\begin{array}{l}3302 \text { at a density } \\
\text { of } 0.47 \mathrm{~g} / \mathrm{cm}^{3} \\
(3677)\end{array}$ & $\begin{array}{l}1.65 \text { at a density } \\
\text { of } 0.47 \mathrm{~g} / \mathrm{cm}^{3} \\
(1.85)\end{array}$ & $\begin{array}{l}\text { Total volumetric } \mathrm{H}_{2} \text { storage capacity of } 46.5 \mathrm{~g} / \mathrm{L} \text { at } 150 \mathrm{bar} \\
\text { and } 77 \mathrm{~K} \text { for pellets with a density of } 0.4-0.467 \mathrm{~g} / \mathrm{cm}^{3}\end{array}$ \\
\hline & Hong et al. [56] & Paste extrusion & & Crystalline & $229.42(345.49)$ & & $\begin{array}{l}\text { Comparable } \mathrm{CO}_{2} \text { adsorption capacity with the MIL-101 (Cr) } \\
\text { powder }\end{array}$ \\
\hline
\end{tabular}

Table 2. The densification method, pelletization pressure, crystallinity, surface area, pore volume, and adsorption/separation/catalysis properties of various MOFs densified in the form of pellets and monoliths. Surface area and pore volume of the powder is given within the brackets for comparison. 


\section{Figure captions}

Fig. 1. The properties of powdered and densified MOFs, indicating significant improvement in volumetric density, mechanical strength, and stability in humid and reactive environments of MOFs with the densification.

Fig. 2. (a) Comparison of BET surface area and total pore volume in MOF-5 powder and pellets, (b) excess gravimetric $\mathrm{H}_{2}$ adsorption in MOF-5 pellets with varying densities at $77 \mathrm{~K}$, and (c) excess volumetric $\mathrm{H}_{2}$ adsorption in MOF-5 pellets with different densities at $77 \mathrm{~K}$. The data from the MOF-5 powder is also shown for the comparison.

Source: Reprinted from Ref. [49] with permission from Elsevier.

Fig. 3. Thermal conductivity of neat and expanded natural graphite (ENG) added MOF-5 pellets as a function of pellet density, amount of ENG, and temperature.

Source: Reprinted from Ref. [45] with permission from Elsevier.

Fig. 4. Comparison of $\mathrm{CO}_{2}$ breakthrough profiles of the UiO-66 powder and ground/sieved pellets with different particle sizes at (a) 1 and (b) 20 bar. (c) Styrene oxide conversion in cycloaddition of $\mathrm{CO}_{2}$ catalyzed by $\mathrm{UiO}-66$ powder and pellets.

Source: Reprinted from Ref. [57] with permission from Elsevier .

Fig. 5. (a) Comparison of water adsorption in CuBTC powder, pellets, 13-X zeolite and activated carbon and (b) $\mathrm{CO}_{2}$ adsorption isotherms of CuBTC (HKUST-1) powder and pellet at 273 and 298 K. (c) Catalytic tetralin conversion by liquid phase oxidation using CuBTC as a catalyst.

Source: Reprinted from Ref. [32] with permission from Elsevier.

Fig. 6. (a) Adsorption isotherms of $\mathrm{H}_{2} \mathrm{~S}$ (triangles), $\mathrm{CO}_{2}$ (circles), and $\mathrm{CH}_{4}$ (squares) at $303 \mathrm{~K}$ for MIL-53(Al) powder (empty symbols) and pellets (filled symbols). (Reprinted from Ref. [60] with permission from Elsevier). (b) Adsorption isotherms of $\mathrm{H}_{2}, \mathrm{~N}_{2}, \mathrm{CH}_{4}$, and $\mathrm{CO}_{2}$ at $283 \mathrm{~K}$ for $\mathrm{NH}_{2}-\mathrm{MIL}-53(\mathrm{Al})$ pellets. (Reprinted from Ref.[103] with permission from American Chemical Society). 
Fig. 7. (a) X-ray diffraction patterns and (b) surface area, total pore volume, and micropore volume of MIL-101(Cr) monoliths with different pellet densities.

Source: Reprinted from Ref. [34] with permission from Elsevier.

Fig. 8. CEC electrochromatograms of xylene isomers (T - thiourea, 1-p-xylene, 2 - m-xylene, 3 - o-xylene) collected from (a) MIL-101 packed column, (b)MIL-101-polymer monolith, and (c) neat polymer monolith.

Source: Reprinted from Ref. [109] with permission from Elsevier .

Fig 9. (a) SEM images and (b) PXRD patterns of ZIF-8 samples synthesized by various posttreatment methods. The PXRD pattern of ZIF-8 powder is also shown for the comparison.

Source: Reprinted from Ref. [65] with permission from Royal Society of Chemistry. 


\section{References}

[1] H. Furukawa, K.E. Cordova, M. O’Keeffe, O.M. Yaghi, Science 341 (2013).

[2] H. Furukawa, U. Müller, O.M. Yaghi, Angew. Chem. Int. Ed. 54 (2015) 3417-3430.

[3] S.L. James, Chem. Soc. Rev. 32 (2003) 276-288.

[4] S. Kitagawa, Chem. Soc. Rev. 43 (2014) 5415-5418.

[5] H.-C. Zhou, J.R. Long, O.M. Yaghi, Chem. Rev. 112 (2012) 673-674.

[6] W. Lu, Z. Wei, Z.-Y. Gu, T.-F. Liu, J. Park, J. Park, J. Tian, M. Zhang, Q. Zhang, T. Gentle Iii, M. Bosch, H.-C. Zhou, Chem. Soc. Rev. 43 (2014) 5561-5593.

[7] N. Stock, S. Biswas, Chem. Rev. 112 (2011) 933-969.

[8] Y. He, W. Zhou, G. Qian, B. Chen, Chem. Soc. Rev. 43 (2014) 5657-5678.

[9] J.-R. Li, Y. Ma, M.C. McCarthy, J. Sculley, J. Yu, H.-K. Jeong, P.B. Balbuena, H.-C. Zhou, Coord. Chem. Rev. 255 (2011) 1791-1823.

[10] J. Liu, P.K. Thallapally, B.P. McGrail, D.R. Brown, J. Liu, Chem. Soc. Rev. 41 (2012) 2308-2322.

[11] M.P. Suh, H.J. Park, T.K. Prasad, D.-W. Lim, Chem. Rev. 112 (2011) 782-835.

[12] K. Sumida, D.L. Rogow, J.A. Mason, T.M. McDonald, E.D. Bloch, Z.R. Herm, T.-H. Bae, J.R. Long, Chem. Rev. 112 (2011) 724-781.

[13] H. Wu, Q. Gong, D.H. Olson, J. Li, Chem. Rev. 112 (2012) 836-868.

[14] J.-R. Li, J. Sculley, H.-C. Zhou, Chem. Rev. 112 (2011) 869-932.

[15] S. Qiu, M. Xue, G. Zhu, Chem. Soc. Rev. 43 (2014) 6116-6140.

[16] B. Van de Voorde, B. Bueken, J. Denayer, D. De Vos, Chem. Soc. Rev. 43 (2014) 5766-5788.

[17] Z. Hu, B.J. Deibert, J. Li, Chem. Soc. Rev. 43 (2014) 5815-5840.

[18] L.E. Kreno, K. Leong, O.K. Farha, M. Allendorf, R.P. Van Duyne, J.T. Hupp, Chem. Rev. 112 (2011) 1105-1125.

[19] B.P. McGrail, P.K. Thallapally, J. Blanchard, S.K. Nune, J.J. Jenks, L.X. Dang, Nano Energy 2 (2013) 845-855.

[20] H.V.R. Annapureddy, S.K. Nune, R.K. Motkuri, B.P. McGrail, L.E.X. Dang, J. Phys. Chem. B 119 (2015) 8992-8999.

[21] A. Dhakshinamoorthy, H. Garcia, Chem. Soc. Rev. 43 (2014) 5750-5765.

[22] J. Liu, L. Chen, H. Cui, J. Zhang, L. Zhang, C.-Y. Su, Chem. Soc. Rev. 43 (2014) 6011-6061.

[23] M. Yoon, R. Srirambalaji, K. Kim, Chem. Rev. 112 (2011) 1196-1231.

[24] T. Zhang, W. Lin, Chem. Soc. Rev. 43 (2014) 5982-5993.

[25] J. Canivet, A. Fateeva, Y. Guo, B. Coasne, D. Farrusseng, Chem. Soc. Rev. 43 (2014) 5594-5617.

[26] E. Barea, C. Montoro, J.A.R. Navarro, Chem. Soc. Rev. 43 (2014) 5419-5430.

[27] J.-W. Jeon, R. Sharma, P. Meduri, B.W. Arey, H.T. Schaef, J.L. Lutkenhaus, J.P. Lemmon, P.K. Thallapally, M.I. Nandasiri, B.P. McGrail, S.K. Nune, ACS Appl. Mater. Interfaces 6 (2014) 7214-7222.

[28] Satish K Nune, Praveen K. Thallapally, Benard Peter McGrail, Harsha V. R. Annapureddy, Liem Xuan Dang, Donghai Mei, Naveen K Karri, Kyle James Alvine, Matthew Olszta, Bruce W. Arey, A. Dohnalkova, ACS Appl. Mater. Interfaces, In Press (2015).

[29] J. Ren, H.W. Langmi, B.C. North, M. Mathe, Int. J. Energy Res. 39 (2015) 607-620.

[30] J. Ren, B.C. North, J. Technol. Innov. Renew. Energy 3 (2014) 12-20.

[31] Z. Jia, H. Li, Z. Yu, P. Wang, X. Fan, Mater. Lett. 65 (2011) 2445-2447.

[32] J. Kim, S.-H. Kim, S.-T. Yang, W.-S. Ahn, Microporous Mesoporous Mater. 161 (2012) 48-55.

[33] D. Bazer-Bachi, L. Assié, V. Lecocq, B. Harbuzaru, V. Falk, Powder Technol. 255 (2014) 52-59.

[34] O. Ardelean, G. Blanita, G. Borodi, M.D. Lazar, I. Misan, I. Coldea, D. Lupu, Int. J. Hydrogen Energy 38 (2013) 7046-7055.

[35] F. Akhtar, L. Andersson, S. Ogunwumi, N. Hedin, L. Bergström, J. Eur. Ceram. Soc. 34 (2014) 1643-1666.

[36] T.D. Bennett, J.-C. Tan, Y. Yue, E. Baxter, C. Ducati, N.J. Terrill, H.H.M. Yeung, Z. Zhou, W. Chen, S. Henke, A.K. Cheetham, G.N. Greaves, Nat. Commun. 6 (2015). 
[37] D. Zacher, O. Shekhah, C. Woll, R.A. Fischer, Chem. Soc. Rev. 38 (2009) 1418-1429.

[38] S. Ma, J. Eckert, P.M. Forster, J.W. Yoon, Y.K. Hwang, J.-S. Chang, C.D. Collier, J.B. Parise, H.-C. Zhou, J. Am. Chem. Soc. 130 (2008) 15896-15902.

[39] V. Finsy, L. Ma, L. Alaerts, D.E. De Vos, G.V. Baron, J.F.M. Denayer, Microporous Mesoporous Mater. 120 (2009) 221-227.

[40] H. Zhang, A.I. Cooper, Chem. Mater. 14 (2002) 4017-4020.

[41] L.D. O'Neill, H. Zhang, D. Bradshaw, J. Mater. Chem. 20 (2010) 5720-5726.

[42] A. Bétard, R.A. Fischer, Chem. Rev. 112 (2012) 1055-1083.

[43] O. Shekhah, J. Liu, R.A. Fischer, C. Woll, Chem. Soc. Rev. 40 (2011) 1081-1106.

[44] S.S. Kaye, A. Dailly, O.M. Yaghi, J.R. Long, J. Am. Chem. Soc. 129 (2007) 14176-14177.

[45] D. Liu, J.J. Purewal, J. Yang, A. Sudik, S. Maurer, U. Mueller, J. Ni, D.J. Siegel, Int. J. Hydrogen Energy 37 (2012) 6109-6117.

[46] Y. Ming, H. Chi, R. Blaser, C. Xu, J. Yang, M. Veenstra, M. Gaab, U. Müller, C. Uher, D.J. Siegel, Int. J. Heat Mass Transfer 82 (2015) 250-258.

[47] Y. Ming, J. Purewal, J. Yang, C. Xu, R. Soltis, J. Warner, M. Veenstra, M. Gaab, U. Müller, D.J. Siegel, Langmuir 31 (2015) 4988-4995.

[48] J. Purewal, D. Liu, A. Sudik, M. Veenstra, J. Yang, S. Maurer, U. Müller, D.J. Siegel, J. Phys. Chem. C 116 (2012) 20199-20212.

[49] J.J. Purewal, D. Liu, J. Yang, A. Sudik, D.J. Siegel, S. Maurer, U. Müller, Int. J. Hydrogen Energy, 37 (2012) 2723-2727.

[50] C. Xu, J. Yang, M. Veenstra, A. Sudik, J.J. Purewal, Y. Ming, B.J. Hardy, J. Warner, S. Maurer, U. Müeller, D.J. Siegel, Int. J. Hydrogen Energy 38 (2013) 3268-3274.

[51] M.V. A. Sudik, J. Yang, U. Muller, E. Leung, D. Siegel, J. Purewal, in, Hydrogen Storage Engineering Center of Excellence, http://hsecoe.org/presentations.html 2010.

[52] G. Blanita, I. Coldea, I. Misan, D. Lupu, Int. J. Hydrogen Energy 39 (2014) 17040-17046.

[53] A. Dailly, E. Poirier, Energy Environ. Sci. 4 (2011) 3527-3534.

[54] H. Oh, D. Lupu, G. Blanita, M. Hirscher, RSC Adv. 4 (2014) 2648-2651.

[55] R. Zacharia, D. Cossement, L. Lafi, R. Chahine, J. Mater. Chem. 20 (2010) 2145-2151.

[56] W.Y. Hong, S.P. Perera, A.D. Burrows, Microporous Mesoporous Mater. 214 (2015) 149-155.

[57] S.-N. Kim, Y.-R. Lee, S.-H. Hong, M.-S. Jang, W.-S. Ahn, Catal. Today 245 (2015) 54-60.

[58] S. Couck, J.F.M. Denayer, G.V. Baron, T. Rémy, J. Gascon, F. Kapteijn, J. Am. Chem. Soc. 131 (2009) 6326-6327.

[59] A.F.P. Ferreira, A.M. Ribeiro, S. Kulaç, A.E. Rodrigues, Chem. Eng. Sci. 124 (2015) 79-95.

[60] N. Heymans, S. Vaesen, G. De Weireld, Microporous Mesoporous Mater. 154 (2012) 93-99.

[61] J. Cousin Saint Remi, T. Rémy, V. Van Hunskerken, S. van de Perre, T. Duerinck, M. Maes, D. De Vos, E. Gobechiya, C.E.A. Kirschhock, G.V. Baron, J.F.M. Denayer, ChemSusChem 4 (2011) 10741077.

[62] J. Ethiraj, F. Bonino, C. Lamberti, S. Bordiga, Microporous Mesoporous Mater. 207 (2015) 90-94.

[63] D. Peralta, G. Chaplais, J.-L. Paillaud, A. Simon-Masseron, K. Barthelet, G.D. Pirngruber, Microporous Mesoporous Mater. 173 (2013) 1-5.

[64] D.F. Sava, M.A. Rodriguez, K.W. Chapman, P.J. Chupas, J.A. Greathouse, P.S. Crozier, T.M. Nenoff, J. Am. Chem. Soc. 133 (2011) 12398-12401.

[65] T. Tian, J. Velazquez-Garcia, T.D. Bennett, D. Fairen-Jimenez, J. Mater. Chem. A 3 (2015) 29993005.

[66] Y.H. Hu, L. Zhang, Phys. Rev. B 81 (2010) 174103.

[67] G.W. Peterson, J.B. DeCoste, F. Fatollahi-Fard, D.K. Britt, Ind. Eng. Chem. Res. 53 (2014) 701-707.

[68] P. Serra-Crespo, E. Stavitski, F. Kapteijn, J. Gascon, RSC Adv. 2 (2012) 5051-5053.

[69] J. Li, S. Cheng, Q. Zhao, P. Long, J. Dong, Int. J. Hydrogen Energy 34 (2009) 1377-1382.

[70] D. Saha, S. Deng, Z. Yang, J. Porous Mater. 16 (2009) 141-149.

[71] K. Sillar, A. Hofmann, J. Sauer, J. Am. Chem. Soc. 131 (2009) 4143-4150.

[72] J. Yang, A. Sudik, C. Wolverton, D.J. Siegel, Chem. Soc. Rev. 39 (2010) 656-675. 
[73] S. Opelt, S. Türk, E. Dietzsch, A. Henschel, S. Kaskel, E. Klemm, Catal. Commun. 9 (2008) 12861290.

[74] P.K. Thallapally, C.A. Fernandez, R.K. Motkuri, S.K. Nune, J. Liu, C.H.F. Peden, Dalton Trans. 39 (2010) 1692-1694.

[75] M. Gallo, D. Glossman-Mitnik, J. Phys. Chem. C 113 (2009) 6634-6642.

[76] J.-R. Li, R.J. Kuppler, H.-C. Zhou, Chem. Soc. Rev. 38 (2009) 1477-1504.

[77] G.J. Halder, C.J. Kepert, B. Moubaraki, K.S. Murray, J.D. Cashion, Science 298 (2002) 1762-1765.

[78] W. Zhou, H. Wu, M.R. Hartman, T. Yildirim, J. Phys. Chem. C 111 (2007) 16131-16137.

[79] S. Hausdorf, J. Wagler, R. Moßig, F.O.R.L. Mertens, J. Phys. Chem. A 112 (2008) 7567-7576.

[80] H. Jasuja, N.C. Burtch, Y.-g. Huang, Y. Cai, K.S. Walton, Langmuir 29 (2013) 633-642.

[81] K. Schrock, F. Schroder, M. Heyden, R.A. Fischer, M. Havenith, Phys. Chem. Chem. Phys. 10 (2008) 4732-4739.

[82] N. Iswarya, M.G. Kumar, K. Rajan, J.B.B. Rayappan, J. Appl. Sci. 12 (2012) 1681-1685.

[83] B.L. Huang, Z. Ni, A. Millward, A.J.H. McGaughey, C. Uher, M. Kaviany, O. Yaghi, Int. J. Heat Mass Transfer 50 (2007) 405-411.

[84] J.H. Cavka, S. Jakobsen, U. Olsbye, N. Guillou, C. Lamberti, S. Bordiga, K.P. Lillerud, J. Am. Chem. Soc. 130 (2008) 13850-13851.

[85] J.B. DeCoste, G.W. Peterson, H. Jasuja, T.G. Glover, Y.-g. Huang, K.S. Walton, J. Mater. Chem. A 1 (2013) 5642-5650.

[86] A.R. Millward, O.M. Yaghi, J. Am. Chem. Soc. 127 (2005) 17998-17999.

[87] W. Morris, C.J. Doonan, O.M. Yaghi, Inorg. Chem. 50 (2011) 6853-6855.

[88] Y.-Y. Fu, C.-X. Yang, X.-P. Yan, Chem. Commun., 49 (2013) 7162-7164.

[89] Q. Yang, A.D. Wiersum, H. Jobic, V. Guillerm, C. Serre, P.L. Llewellyn, G. Maurin, J. Phys. Chem. C 115 (2011) 13768-13774.

[90] M. Kandiah, M.H. Nilsen, S. Usseglio, S. Jakobsen, U. Olsbye, M. Tilset, C. Larabi, E.A. Quadrelli, F. Bonino, K.P. Lillerud, Chem. Mater. 22 (2010) 6632-6640.

[91] K. Leus, P. Concepcion, M. Vandichel, M. Meledina, A. Grirrane, D. Esquivel, S. Turner, D. Poelman, M. Waroquier, V. Van Speybroeck, G. Van Tendeloo, H. Garcia, P. Van Der Voort, RSC Adv. 5 (2015) 22334-22342.

[92] P.S. Bárcia, D. Guimarães, P.A.P. Mendes, J.A.C. Silva, V. Guillerm, H. Chevreau, C. Serre, A.E. Rodrigues, Microporous Mesoporous Mater. 139 (2011) 67-73.

[93] M.A. Moreira, J.C. Santos, A.F.P. Ferreira, J.M. Loureiro, F. Ragon, P. Horcajada, K.-E. Shim, Y.K. Hwang, U.H. Lee, J.-S. Chang, C. Serre, A.E. Rodrigues, Langmuir 28 (2012) 5715-5723.

[94] J. Liu, Y. Wang, A.I. Benin, P. Jakubczak, R.R. Willis, M.D. LeVan, Langmuir, 26 (2010) 1430114307.

[95] G.W. Peterson, J.B. DeCoste, T.G. Glover, Y. Huang, H. Jasuja, K.S. Walton, Microporous Mesoporous Mater. 179 (2013) 48-53.

[96] D.F. Sava, K.W. Chapman, M.A. Rodriguez, J.A. Greathouse, P.S. Crozier, H. Zhao, P.J. Chupas, T.M. Nenoff, Chem. Mater. 25 (2013) 2591-2596.

[97] B. Xiao, P.S. Wheatley, X. Zhao, A.J. Fletcher, S. Fox, A.G. Rossi, I.L. Megson, S. Bordiga, L. Regli, K.M. Thomas, R.E. Morris, J. Am. Chem. Soc.,129 (2007) 1203-1209.

[98] A. Ahmed, M. Forster, R. Clowes, P. Myers, H. Zhang, Chem. Commun. 50 (2014) 14314-14316.

[99] J. Liu, P.K. Thallapally, D. Strachan, Langmuir 28 (2012) 11584-11589.

[100] S.S.-Y. Chui, S.M.-F. Lo, J.P.H. Charmant, A.G. Orpen, I.D. Williams, Science 283 (1999) 11481150.

[101] A. Schneemann, V. Bon, I. Schwedler, I. Senkovska, S. Kaskel, R.A. Fischer, Chem. Soc. Rev. 43 (2014) 6062-6096.

[102] T. Remy, L. Ma, M. Maes, D.E. De Vos, G.V. Baron, J.F.M. Denayer, Ind. Eng. Chem. Res. 51 (2012) 14824-14833.

[103] E. Stavitski, E.A. Pidko, S. Couck, T. Remy, E.J.M. Hensen, B.M. Weckhuysen, J. Denayer, J. Gascon, F. Kapteijn, Langmuir 27 (2011) 3970-3976. 
[104] G. Férey, C. Mellot-Draznieks, C. Serre, F. Millange, J. Dutour, S. Surblé, I. Margiolaki, Science 309 (2005) 2040-2042.

[105] M. Latroche, S. Surblé, C. Serre, C. Mellot-Draznieks, P.L. Llewellyn, J.-H. Lee, J.-S. Chang, S.H. Jhung, G. Férey, Angew. Chem. Int. Ed. 45 (2006) 8227-8231.

[106] L. Hamon, C. Serre, T. Devic, T. Loiseau, F. Millange, G. Férey, G.D. Weireld, J. Am. Chem. Soc. 131 (2009) 8775-8777.

[107] P.L. Llewellyn, S. Bourrelly, C. Serre, A. Vimont, M. Daturi, L. Hamon, G. De Weireld, J.-S. Chang, D.-Y. Hong, Y. Kyu Hwang, S. Hwa Jhung, G. Férey, Langmuir 24 (2008) 7245-7250.

[108] M. Wickenheisser, A. Herbst, R. Tannert, B. Milow, C. Janiak, Microporous Mesoporous Mater. 215 (2015) 143-153.

[109] H.-Y. Huang, C.-L. Lin, C.-Y. Wu, Y.-J. Cheng, C.-H. Lin, Anal. Chim. Acta 779 (2013) 96-103.

[110] C.-X. Yang, X.-P. Yan, Anal. Chem. 83 (2011) 7144-7150.

[111] J.J. Low, A.I. Benin, P. Jakubczak, J.F. Abrahamian, S.A. Faheem, R.R. Willis, J. Am. Chem. Soc. 131 (2009) 15834-15842.

[112] X.-C. Huang, Y.-Y. Lin, J.-P. Zhang, X.-M. Chen, Angew. Chem. Int. Ed. 45 (2006) 1557-1559.

[113] K.S. Park, Z. Ni, A.P. Côté, J.Y. Choi, R. Huang, F.J. Uribe-Romo, H.K. Chae, M. O’Keeffe, O.M. Yaghi, PNAS 103 (2006) 10186-10191.

[114] T.D. Bennett, P.J. Saines, D.A. Keen, J.-C. Tan, A.K. Cheetham, Chem. Eur. J. 19 (2013) 70497055.

[115] W. Morris, B. Leung, H. Furukawa, O.K. Yaghi, N. He, H. Hayashi, Y. Houndonougbo, M. Asta, B.B. Laird, O.M. Yaghi, J. Am. Chem. Soc. 132 (2010) 11006-11008.

[116] J. Pérez-Pellitero, H. Amrouche, F.R. Siperstein, G. Pirngruber, C. Nieto-Draghi, G. Chaplais, A. Simon-Masseron, D. Bazer-Bachi, D. Peralta, N. Bats, Chem. Eur. J. 16 (2010) 1560-1571.

[117] K. Zhang, R.P. Lively, M.E. Dose, A.J. Brown, C. Zhang, J. Chung, S. Nair, W.J. Koros, R.R. Chance, Chem. Commun. 49 (2013) 3245-3247.

[118] H. Bux, C. Chmelik, R. Krishna, J. Caro, J. Membr. Sci. 369 (2011) 284-289.

[119] A. Huang, Y. Chen, N. Wang, Z. Hu, J. Jiang, J. Caro, Chem. Commun. 48 (2012) 10981-10983.

[120] H.T. Kwon, H.-K. Jeong, J. Am. Chem. Soc. 135 (2013) 10763-10768.

[121] Y. Pan, T. Li, G. Lestari, Z. Lai, J. Membr. Sci. 390-391 (2012) 93-98.

[122] Q. Song, S.K. Nataraj, M.V. Roussenova, J.C. Tan, D.J. Hughes, W. Li, P. Bourgoin, M.A. Alam, A.K. Cheetham, S.A. Al-Muhtaseb, E. Sivaniah, Energy Environ. Sci. 5 (2012) 8359-8369.

[123] O. Karagiaridi, M.B. Lalonde, W. Bury, A.A. Sarjeant, O.K. Farha, J.T. Hupp, J. Am. Chem. Soc. 134 (2012) 18790-18796.

[124] C.-H. Kuo, Y. Tang, L.-Y. Chou, B.T. Sneed, C.N. Brodsky, Z. Zhao, C.-K. Tsung, J. Am. Chem. Soc. 134 (2012) 14345-14348.

[125] L.T.L. Nguyen, K.K.A. Le, H.X. Truong, N.T.S. Phan, Catal. Sci. Technol. 2 (2012) 521-528.

[126] M. Zhu, D. Srinivas, S. Bhogeswararao, P. Ratnasamy, M.A. Carreon, Catal. Commun. 32 (2013) 36-40.

[127] R. Banerjee, A. Phan, B. Wang, C. Knobler, H. Furukawa, M. O'Keeffe, O.M. Yaghi, Science 319 (2008) 939-943.

[128] D. Fairen-Jimenez, S.A. Moggach, M.T. Wharmby, P.A. Wright, S. Parsons, T. Düren, J. Am. Chem. Soc. 133 (2011) 8900-8902.

[129] H. Bux, F. Liang, Y. Li, J. Cravillon, M. Wiebcke, J. Caro, J. Am. Chem. Soc. 131 (2009) 1600016001.

[130] R.C. Ewing, F.N. von Hippel, Science 325 (2009) 151-152.

[131] E. Kintisch, Science 310 (2005) 1406.

[132] W. Lee, M. Ojovan, M. Stennett, N. Hyatt, Adv. Appl. Ceram. 105 (2006) 3-12.

[133] K.W. Chapman, P.J. Chupas, T.M. Nenoff, J. Am. Chem. Soc. 132 (2010) 8897-8899.

[134] D.F. Sava, T.J. Garino, T.M. Nenoff, Ind. Eng. Chem. Res., 51 (2012) 614-620.

[135] M.-H. Zeng, Q.-X. Wang, Y.-X. Tan, S. Hu, H.-X. Zhao, L.-S. Long, M. Kurmoo, J. Am. Chem.

Soc. 132 (2010) 2561-2563. 
[136] L. Diestel, H. Bux, D. Wachsmuth, J. Caro, Microporous Mesoporous Mater. 164 (2012) 288-293. [137] D. Peralta, G. Chaplais, A. Simon-Masseron, K. Barthelet, G.D. Pirngruber, Ind. Eng. Chem. Res. 51 (2012) 4692-4702.

[138] D. Antoni, V. Zverlov, W. Schwarz, Appl. Microbiol. Biotechnol. 77 (2007) 23-35.

[139] A. Demirbas, Energy Sources A 31 (2009) 1056-1062.

[140] M. García, M.T. Sanz, S. Beltrán, J. Chem. Technol. Biotechnol. 84 (2009) 1873-1882.

[141] F. Liu, L. Liu, X. Feng, Sep. Purif. Technol. 42 (2005) 273-282.

[142] A. Oudshoorn, L.A.M. van der Wielen, A.J.J. Straathof, Biochem. Eng. J. 48 (2009) 99-103.

[143] N. Qureshi, S. Hughes, I.S. Maddox, M.A. Cotta, Bioprocess Biosyst. Eng. 27 (2005) 215-222.

[144] C. Chizallet, S. Lazare, D. Bazer-Bachi, F. Bonnier, V. Lecocq, E. Soyer, A.-A. Quoineaud, N. Bats, J. Am. Chem. Soc. 132 (2010) 12365-12377.

[145] J. Ren, N.M. Musyoka, H.W. Langmi, A. Swartbooi, B.C. North, M. Mathe, Int. J. Hydrogen Energy 40 (2015) 4617-4622. 
Figure 1

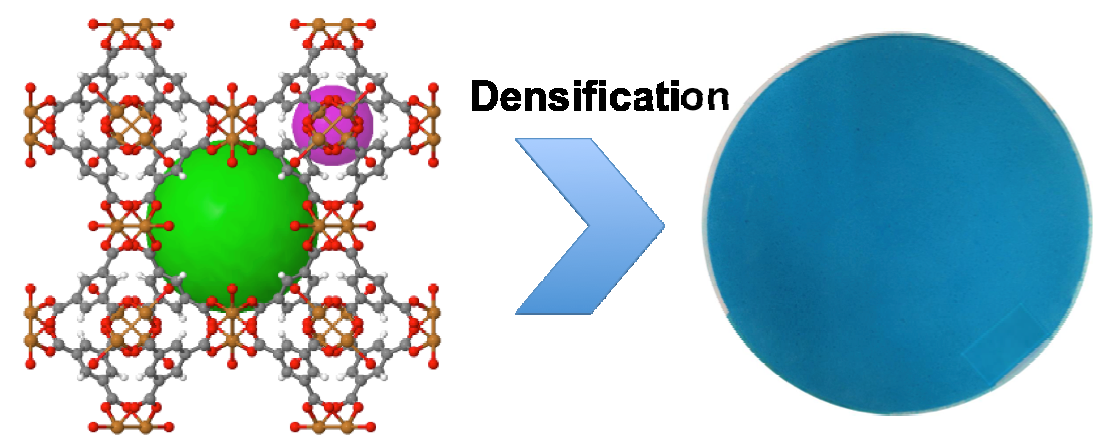

\begin{tabular}{ccc}
\hline Properties & Powdered MOFs & Densified MOFs \\
\hline Mechanical strength & low & high \\
Thermal conductivity & low & high \\
Packing density & low & high \\
Stability towards water & poor & better \\
Chemical stability & poor & better \\
Volumetric density & low & high \\
Gravimetric density & high & compromised \\
Surface area & high & compromised \\
Pore volume & high & compromised \\
Crystallinity & crystalline & reduced crystallinity \\
\hline
\end{tabular}


Figure 2

(a)

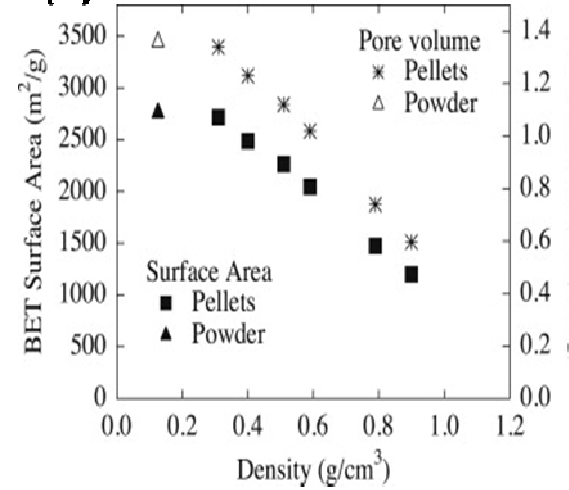

(b)

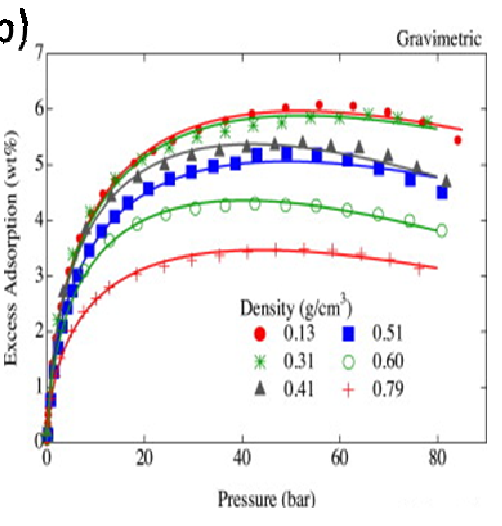

(c)

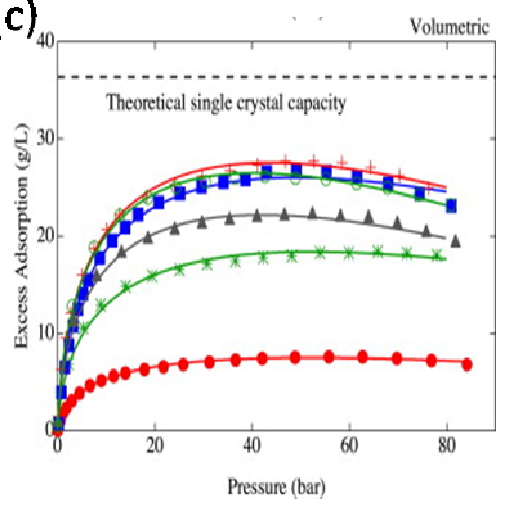


Figure 3

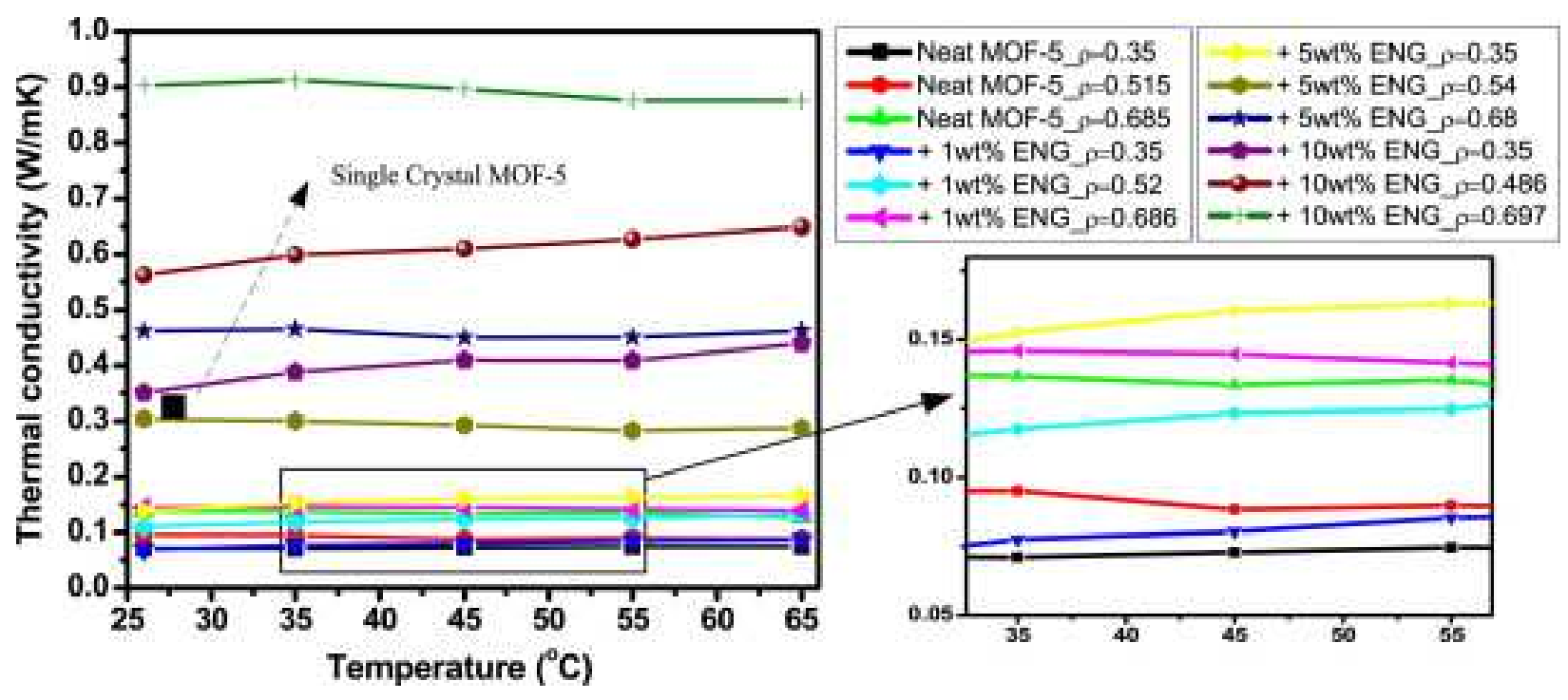


Figure 4

(a)

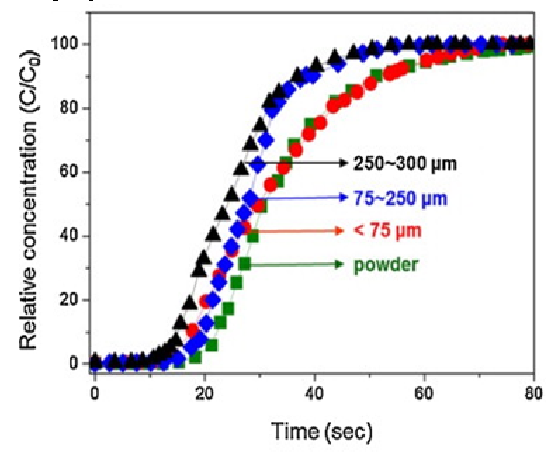

(b)

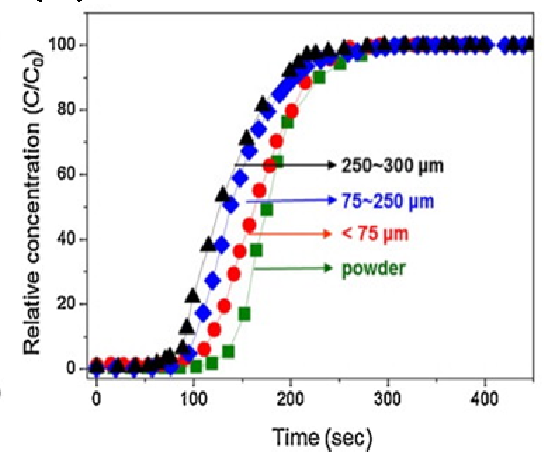

(c)

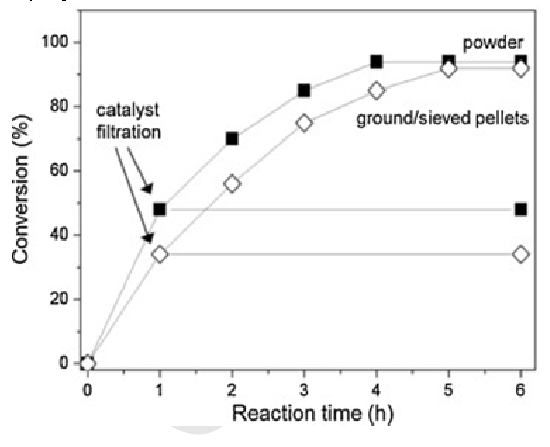


Figure 5

(a)

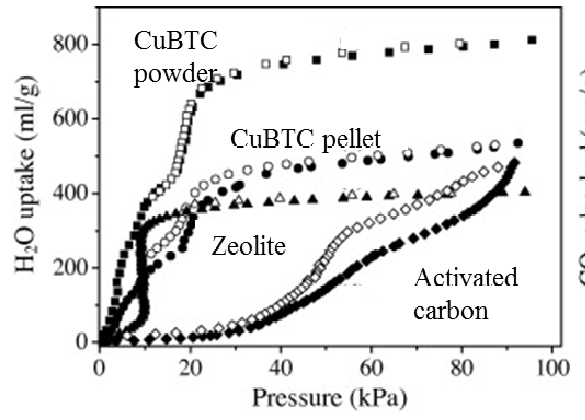

(b)

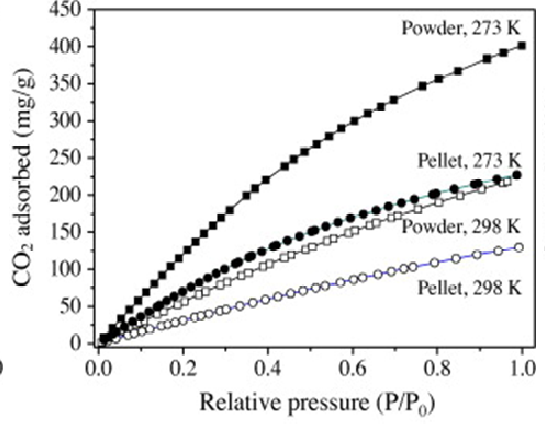

(c)

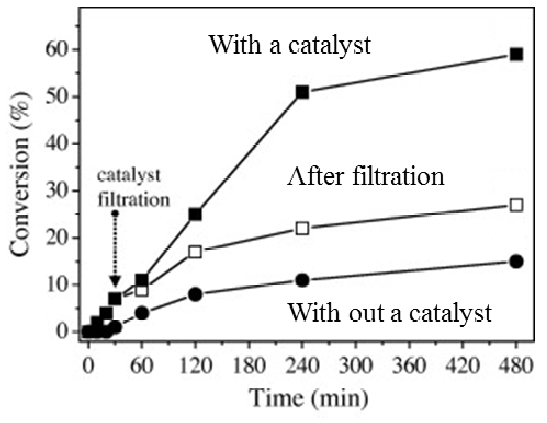


Figure 6

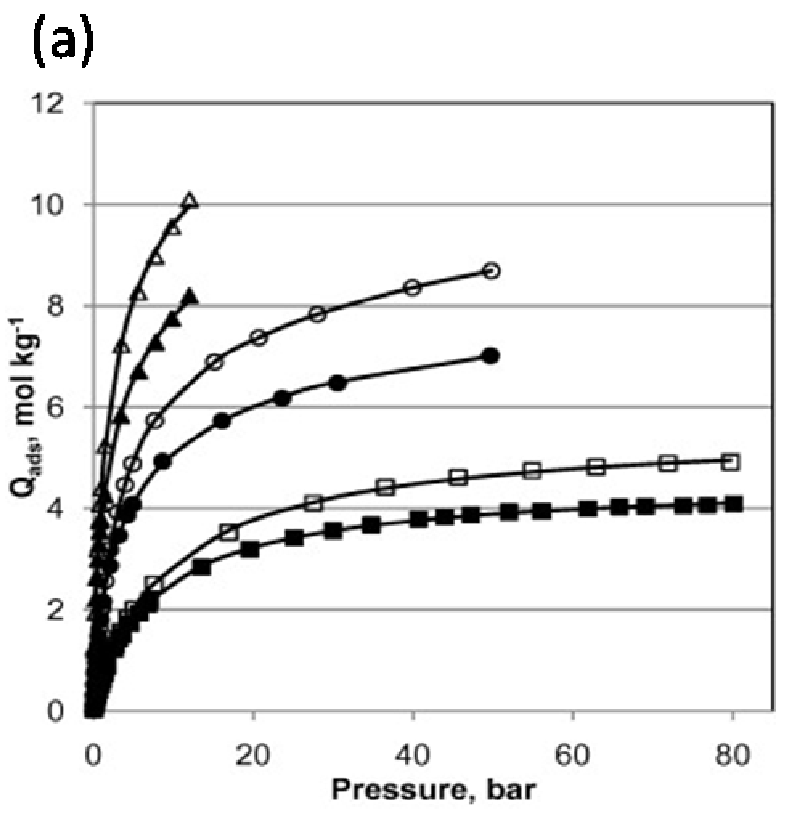

(b)

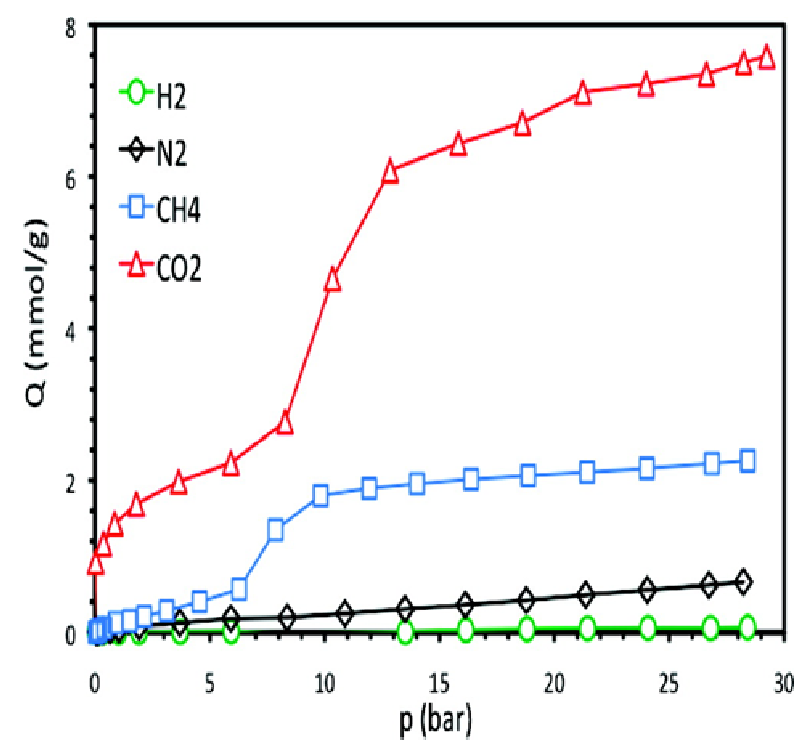


Figure 7

(a)

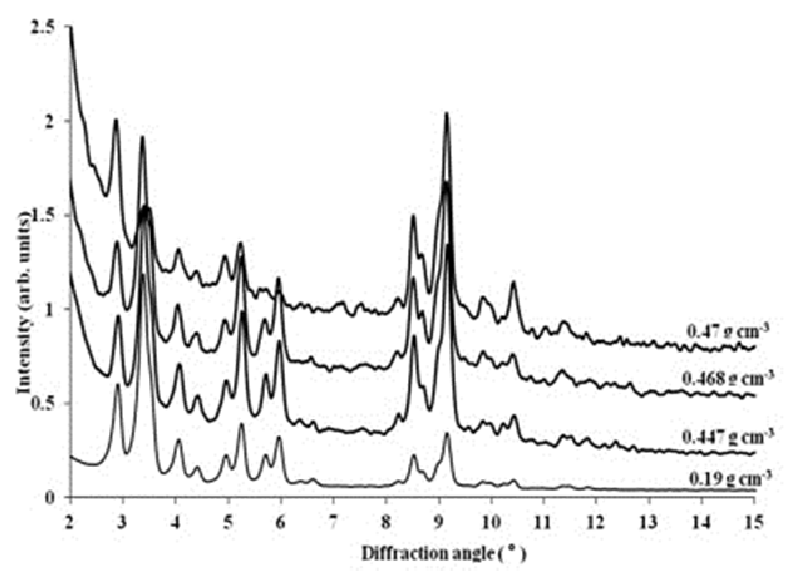

(b)

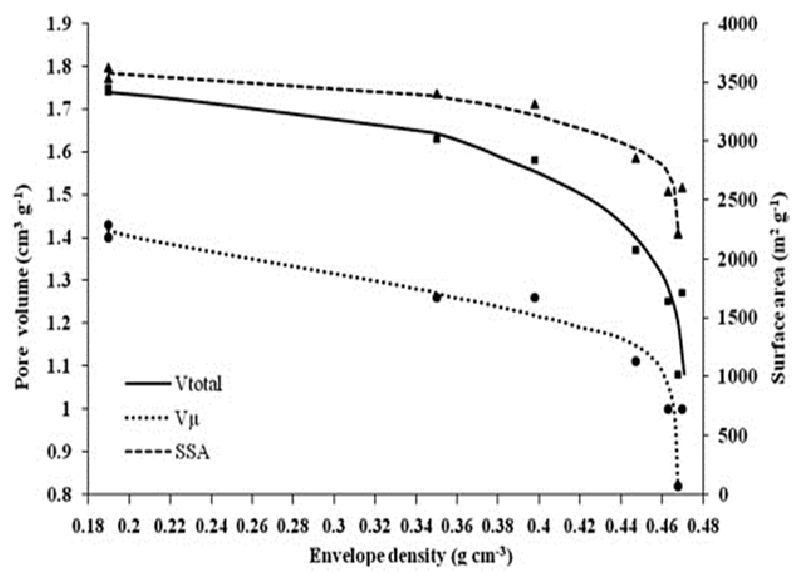


Figure 8

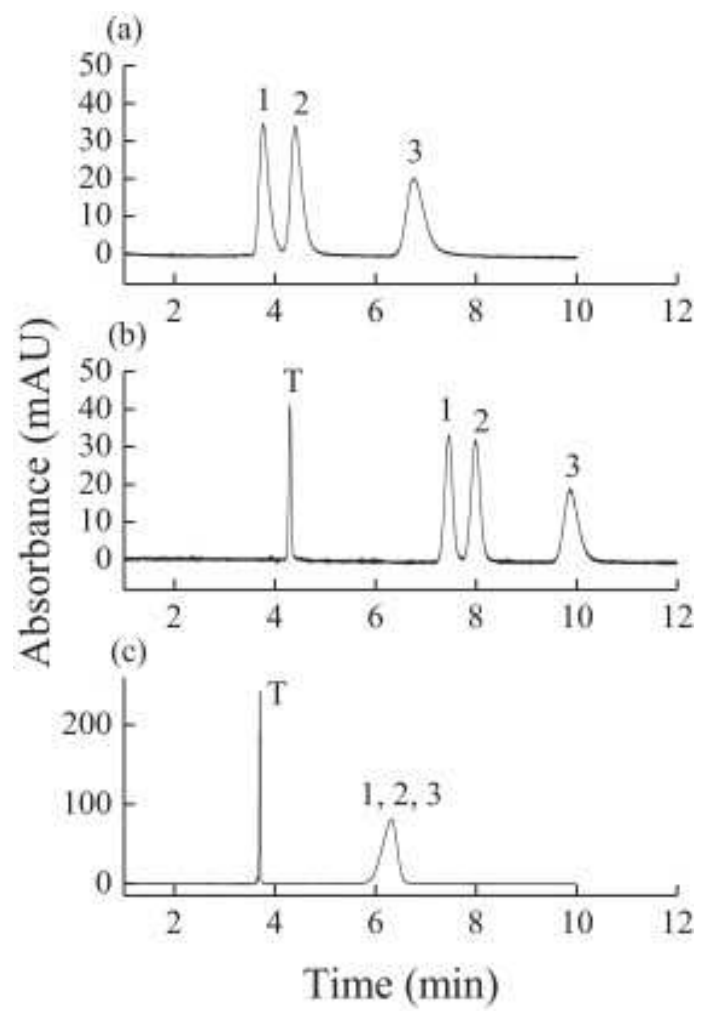

Page 44 of 46 
Figure 9
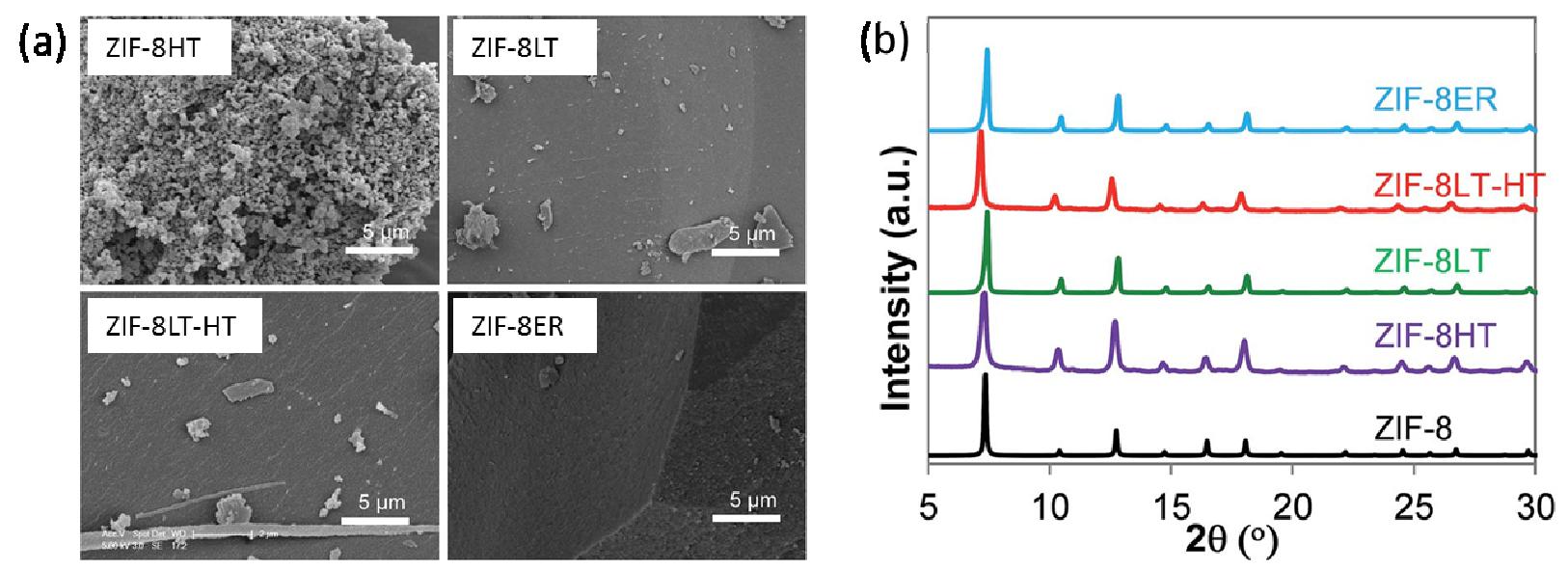